Article

\title{
Coordination Behavior of 1,4-Disubstituted Cyclen Endowed with Phosphonate, Phosphonate Monoethylester, and H-Phosphinate Pendant Arms
}

\author{
Jiří Bárta (D), Petr Hermann $(\mathbb{D}$ and Jan Kotek *(D) \\ Department of Inorganic Chemistry, Faculty of Science, Charles University, Hlavova 8, \\ 12843 Prague 2, Czech Republic; BJRS@seznam.cz (J.B.); petrh@natur.cuni.cz (P.H.) \\ * Correspondence: modrej@natur.cuni.cz
}

Received: 29 August 2019; Accepted: 8 September 2019; Published: 12 September 2019

check for updates

\begin{abstract}
Three 1,4,7,10-tetraazacyclododecane-based ligands disubstituted in 1,4-positions with phosphonic acid, phosphonate monoethyl-ester, and H-phosphinic acid pendant arms, 1,4- $\mathrm{H}_{4} \mathrm{do} 2 \mathrm{p}$, 1,4- $\mathrm{H}_{2} \mathrm{do} 2 \mathrm{p}^{\mathrm{OEt}}$, and 1,4- $\mathrm{H}_{2} \mathrm{Bn}_{2} \mathrm{do} 2 \mathrm{p}^{\mathrm{H}}$, were synthesized and their coordination to selected metal ions, $\mathrm{Mg}(\mathrm{II}), \mathrm{Ca}(\mathrm{II}), \mathrm{Mn}(\mathrm{II}), \mathrm{Zn}(\mathrm{II}), \mathrm{Cu}(\mathrm{II}), \mathrm{Eu}(\mathrm{III}), \mathrm{Gd}(\mathrm{III})$, and $\mathrm{Tb}(\mathrm{III})$, was investigated. The solid-state structure of the phosphonate ligand, 1,4- $\mathrm{H}_{4} \mathrm{do} 2 \mathrm{p}$, was determined by single-crystal X-ray diffraction. Protonation constants of the ligands and stability constants of their complexes were obtained by potentiometry, and their values are comparable to those of previously studied analogous 1,7-disubstitued cyclen derivatives. The Gd(III) complex of $1,4-\mathrm{H}_{4} \mathrm{do} 2 \mathrm{p}$ is $\sim 1$ order of magnitude more stable than the Gd(III) complex of the 1,7-analogue, probably due to the disubstituted ethylenediamine-like structural motif in 1,4- $\mathrm{H}_{4} \mathrm{do} 2 \mathrm{p}$ enabling more efficient wrapping of the metal ion. Stability of $\mathrm{Gd}(\mathrm{III})-1,4-\mathrm{H}_{2} \mathrm{do} 2 \mathrm{p}^{\mathrm{OEt}}$ and $\mathrm{Gd}(\mathrm{III})-\mathrm{H}_{2} \mathrm{Bn}_{2} \mathrm{do} 2 \mathrm{p}^{\mathrm{H}}$ complexes is low and the constants cannot be determined due to precipitation of the metal hydroxide. Protonations of the $\mathrm{Cu}$ (II), $\mathrm{Zn}$ (II), and Gd(III) complexes probably takes place on the coordinated phosphonate groups. Complexes of $\mathrm{Mn}(\mathrm{II})$ and alkali-earth metal ions are significantly less stable and are not formed in acidic solutions. Potential presence of water molecule(s) in the coordination spheres of the Mn(II) and Ln(III) complexes was studied by variable-temperature NMR experiments. The Mn(II) complexes of the ligands are not hydrated. The $\mathrm{Gd}(\mathrm{III})-1,4-\mathrm{H}_{4} \mathrm{do} 2 \mathrm{p}$ complex undergoes hydration equilibrium between monoand bis-hydrated species. Presence of two-species equilibrium was confirmed by UV-Vis spectroscopy of the $\mathrm{Eu}(\mathrm{III})-1,4-\mathrm{H}_{4} \mathrm{do} 2 \mathrm{p}$ complex and hydration states were also determined by luminescence measurements of the $\mathrm{Eu}(\mathrm{III}) / \mathrm{Tb}(\mathrm{III})-1,4-\mathrm{H}_{4}$ do2p complexes.
\end{abstract}

Keywords: macrocyclic ligands; metal complexes; manganese; gadolinium; copper; MRI contrast agents; phosphonate ligands; phosphinate ligands; cyclen derivatives; protonation constants; stability constants

\section{Introduction}

Stable metal chelates belong to a group of intensively studied compounds due to their various applications. Importance of the research has been proven, e.g., by nearly four decades of development of magnetic resonance imaging (MRI) where such paramagnetic complexes are used as contrast agents (CAs). A wide application scope of MRI and its great impact on healthcare have been a driving force behind the MRI CAs development focusing on complexes of Gd(III) and Mn(II) ions [1-10]. Due to a toxicity of the metal ions (doses of the CAs used for an efficient contrast enhancement are relatively high and exceed a lethal dose of the "free" aqua metal ions), the ions have to be bound in stable complexes which should contain at least one water molecule coordinated directly to the metal ion 
centre. This metal-bound water molecule is responsible for relaxation enhancement of the ${ }^{1} \mathrm{H}$ MRI signal due to its exchange with the bulk water which is observed by MRI [11].

Almost all MRICAs utilized in clinical practice till now have been based on Gd(III). Their safety was challenged after observation of nephrogenic systemic fibrosis (NSF). The disease has been connected with a use of $\mathrm{Gd}(\mathrm{III})$ chelates with several open-chain ligands, namely bis(amide) derivatives of $\mathrm{H}_{5} \mathrm{dtpa}[12-14]$ and they were withdrawn from the market. Therefore nowadays, a utilization of more stable macrocyclic chelates is strongly preferred (e.g., $\mathrm{H}_{4}$ dota, Figure 1, and its derivatives and analogues). In vivo stability of the MRI CAs is given by thermodynamic stability of the complexes and, mainly, by their kinetic inertness, and both properties have been intensively studied.

Therefore, alternatives to the Gd-based MRI CAs have been sought. A significant effort has been paid to investigations of Mn(II)-based CAs as Mn(II) is an essential biogenic metal ion (serving e.g., as a cofactor in a number of enzymes) [15] and it has a lower toxicity if compared to $\mathrm{Gd}(\mathrm{III})$. The relatively low toxicity of $\mathrm{Mn}(\mathrm{II})$ even enables use of simple salts, such as $\mathrm{MnCl}_{2}$, in the specific imaging field called manganese enhanced MRI (MEMRI) [16] which allows detailed study of brain structure and local brain/neuronal or cardiac function due to similarity of $\mathrm{Mn}$ (II) ionic radius with that of $\mathrm{Ca}(\mathrm{II})$ and its ability to substitute this ion in biological processes. However, it is limited only to experimental work with small animals as $\mathrm{Mn}(\mathrm{II})$ is anyway toxic at concentrations needed to provide a sufficient contrast $\left(\mathrm{LD}_{50}\left(\mathrm{MnCl}_{2}\right)=0.22 \mathrm{mmol} \mathrm{kg}{ }^{-1}\right.$ in rat) [17]. In human medicine, Teslascan ${ }^{\circledR}\left([\mathrm{Mn}(\mathrm{dpdp})]^{4-}\right.$, where $\mathrm{dpdp}^{6-}=N, N^{\prime}$-dipyridoxyl-ethylenediamine- $N, N^{\prime}$-diacetate5,5'-bis(phosphate)) (Figure 1) [18], was approved for liver, kidney, and cardiac imaging [19,20]. This compound does not directly coordinate water molecules and its effectiveness lies in a slow release of free $\mathrm{Mn}$ (II)-aqua complex from the chelate (its slow dissociation restrains acute toxicity potentially inflicted by a direct application of the same dose as e.g., $\mathrm{MnCl}_{2}$ ). However, accumulation of $\mathrm{Mn}$ (II) in the brain has been proven [21], and overexposure to $\mathrm{Mn}$ (II) can lead to neurological disorders resulting in a form of parkinsonism termed manganism [22]. Therefore, careful ligand design still remains a crucial point also in the area of the Mn(II)-based CAs.

Other important field of utilization of metal chelates with polydentate ligands is nuclear medicine where metal radionuclides are used. Over the last years, a number of metal radioisotopes with properties useful for both radiodiagnosis and radiotherapy have become widely available. Therefore, there is a need for (optimally macrocyclic) ligands able to selectively complex metal ions as Ga(III), $\mathrm{Sc}(\mathrm{III}), \mathrm{Y}(\mathrm{III})$, lanthanides(III), $\mathrm{Cu}(\mathrm{II}), \mathrm{In}(\mathrm{III})$, or Bi(III) [23-27]. These facts make research on macrocyclic ligating systems a vital part of modern coordination chemistry.
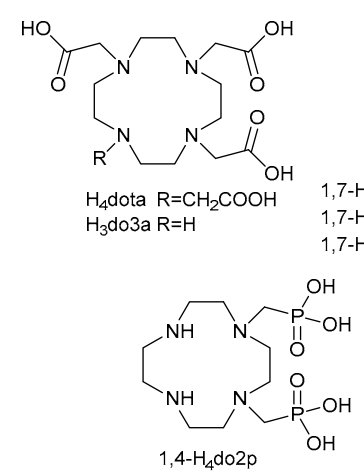

Figure 1. Structural formulas of the ligands discussed in the text.
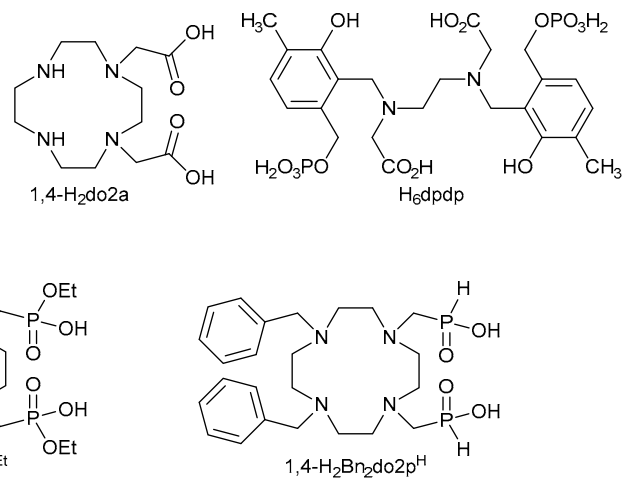

To contribute to the field, we decided to study a series of ligands based on 1,4,7,10-tetraazacyclododecane (cyclen) endowed by two coordinating pendant arms bound in its 1,4-positions as data on this family of ligands are almost missing in the literature. Only both analogous acetate derivatives (1,4- and 1,7-bis(carboxymethyl) cyclen derivatives, 1,4- $\mathrm{H}_{2} \mathrm{do} 2 \mathrm{a}$ and 1,7- $\mathrm{H}_{2} \mathrm{do} 2 \mathrm{a}$, respectively, Figure 1) have been reported and studied [28-33]. Among their phosphorus acid 
analogues, only isomeric 1,7-bis(methylenephosphonic acid) derivative $\left(1,7-\mathrm{H}_{4} \mathrm{do} 2 \mathrm{p}\right.$, Figure 1$)$ and its bis(monoethyl-ester) $\left(1,7-\mathrm{H}_{2} \mathrm{do} 2 \mathrm{p}^{\mathrm{OEt}}\right.$, Figure 1) have been reported and the Mn(II) complex of 1,7- $\mathrm{H}_{4} \mathrm{do} 2 \mathrm{p}$ has been investigated [34]. Here we report on synthesis of three new ligands, 1,4- $\mathrm{H}_{4} \mathrm{do} 2 \mathrm{p}, 1,4-\mathrm{H}_{2} \mathrm{do} 2 \mathrm{p}$ OEt, and $1,4-\mathrm{H}_{2} \mathrm{Bn}_{2} \mathrm{do} 2 \mathrm{p}^{\mathrm{H}}$ (with phosphonate, phosphonate monoethyl ester, and H-phosphinate pendant moieties, Figure 1), and on their coordination chemistry with selected metal ions relevant for medicinal imaging techniques.

\section{Results and Discussion}

\subsection{Synthesis}

Synthesis of the studied ligands $1,4-\mathrm{H}_{4} \mathrm{do} 2 \mathrm{p}, 1,4-\mathrm{H}_{2} \mathrm{do} 2 \mathrm{p}^{\mathrm{OEt}}$, and $1,4-\mathrm{H}_{2} \mathrm{Bn}_{2} \mathrm{do} 2 \mathrm{p}^{\mathrm{H}}$, is shown in Scheme 1. The starting 1,4-dibenzyl-1,4,7,10-tetraazacyclododecane (1) was prepared by a slight modification of the literature method. Compared to the reported procedure [35], ethanol was added into the reaction mixture for better solubility of the starting oxalyl-protected dibenzylcyclen during its basic hydrolysis (see ESI).

Diethyl phosphonomethyl moieties were introduced by a Mannich-type reaction (under analogous conditions as those reported in literature [36]) to obtain compound 2. Hydrogenolysis of 2 using $\mathrm{H}_{2}$ and $\mathrm{Pd} / \mathrm{C}$ as a catalyst afforded compound 3 . Trials to fully hydrolyse this compound to the required ligand $1,4-\mathrm{H}_{4}$ do2 $\mathrm{p}$ failed-acid hydrolysis (heating in aq. $\mathrm{HCl}$ ) led to rich mixtures. However, basic hydrolysis $[37,38]$ of the compound 3 in aq. $\mathrm{NaOH}$ selectively led to the bis-monoesterified ligand $1,4-\mathrm{H}_{2} \mathrm{do} 2 \mathrm{p}^{\mathrm{OEt}}$. Thus, the ligand 1,4- $\mathrm{H}_{4} \mathrm{do} 2 \mathrm{p}$ was prepared by a reversed approach. In the first step, ethyl ester groups were removed by trans-esterification with trimethylsilyl bromide and the silyl ester hydrolysis with aq. $\mathrm{MeOH}$, affording intermediate 4. Surprisingly in this step, the classical acid hydrolysis of 2, i.e., heating in aq. $\mathrm{HCl}$, did not lead to any ester hydrolysis. In the second step, benzyl groups were removed by a trans-acylation approach. Thus first, full silyl ester soluble in anhydrous media was prepared, benzyl groups were removed in reaction with benzyl chloroformate (Z-Cl) and the carbamate group was hydrolyzed in $\mathrm{HBr} / \mathrm{AcOH}$, similarly as reported in literature [39]. Hydrogenolysis of compound $4\left(\mathrm{H}_{2}, \mathrm{Pd} / \mathrm{C}\right.$ catalyst) was not successful, probably due to a low solubility of the compound 4 in several acidic solvents.
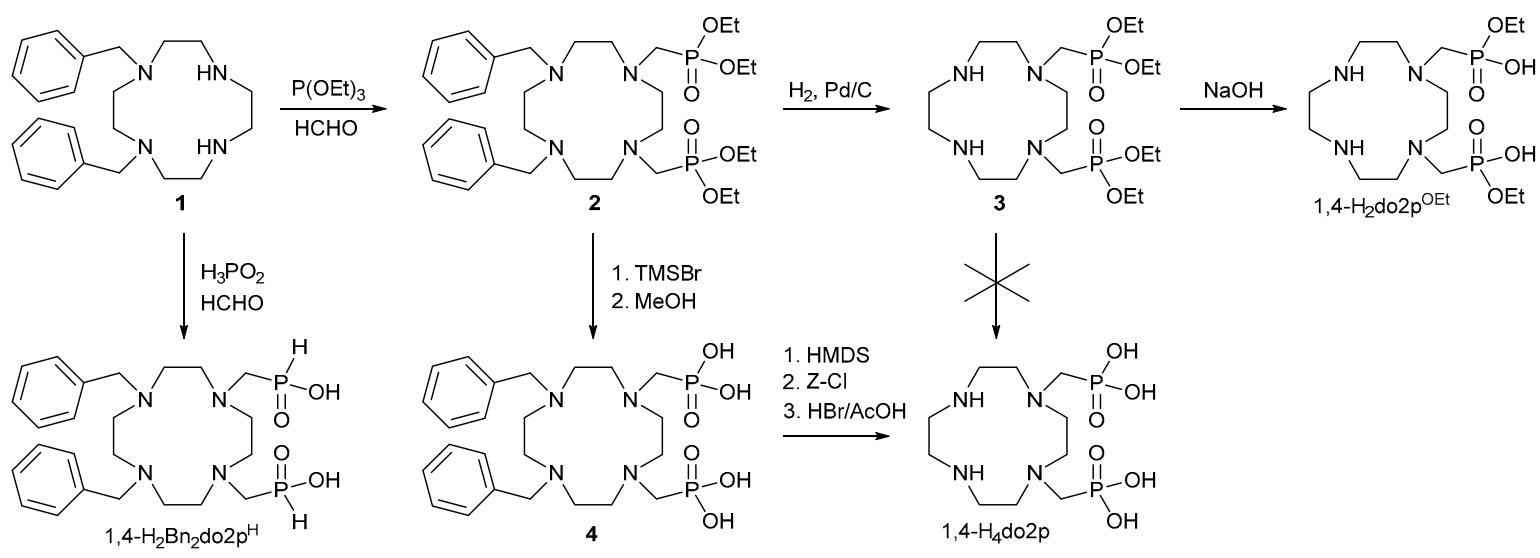

Scheme 1. Synthesis of the studied ligands.

To synthesize 1,4- $\mathrm{H}_{2} \mathrm{Bn}_{2} \mathrm{do} 2 \mathrm{p}^{\mathrm{H}}$, reaction between $\mathbf{1}$, hypophosphorus acid and paraformaldehyde in acid media was employed. Removal of benzyl groups in the compound either by hydrogenation $\left(\mathrm{H}_{2}, \mathrm{Pd} / \mathrm{C}\right.$ catalyst) or trans-acylation (using $\mathrm{Z}-\mathrm{Cl}$, as described above) was not successful as rich mixtures of various products were obtained. Therefore, the benzylated derivative $1,4-\mathrm{H}_{2} \mathrm{Bn}_{2} \mathrm{do} 2 \mathrm{p}^{\mathrm{H}}$ was further studied as an example of a ligand with $\mathrm{H}$-phosphinic acid pendant arms.

Tetrahydrate of $1,4-\mathrm{H}_{4} \mathrm{do} 2 \mathrm{p}$ was studied by single-crystal X-ray diffraction. In the solid state, the molecule has a zwitterionic structure where each phosphonate pendant moiety is singly protonated 
and the other two protons are located on mutually trans macrocycle amino groups (Figure 2). Both pendant arms point to the same half-space with respect to the macrocycle ring and are mutually interacting through a strong intramolecular hydrogen bond $\left(d_{\mathrm{O} 11 \cdots \mathrm{O} 22}=2.60 \AA\right)$. Intramolecular hydrogen bonds involving the macrocycle amino groups stabilize the ring in $(3,3,3,3)$-B conformation [40] (Table S1). All four water molecules of crystallization participate in a wide intermolecular hydrogen bond network (Figure S1, Table S1).

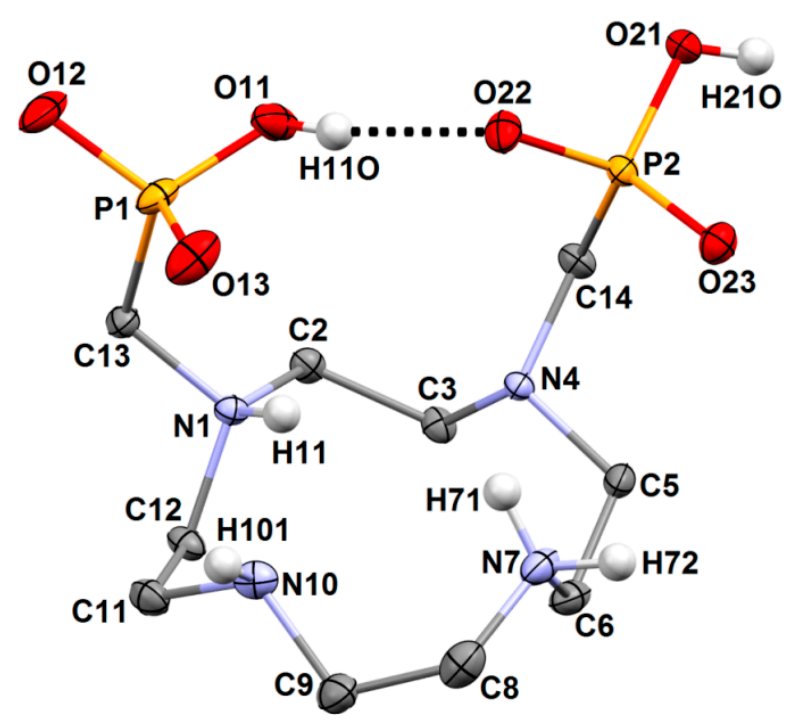

Figure 2. Molecular structure of $1,4-\mathrm{H}_{4} \mathrm{do} 2 \mathrm{p}$ found in the crystal structure of $1,4-\mathrm{H}_{4} \mathrm{do} 2 \mathrm{p} \cdot 4 \mathrm{H}_{2} \mathrm{O}$. Carbon-bound hydrogen atoms are omitted for clarity. The intramolecular hydrogen bond is shown by the dotted line.

\subsection{Protonation of the Ligands and Stability of Their Complexes}

Stepwise protonation constants of 1,4- $\mathrm{H}_{4} \mathrm{do} 2 \mathrm{p}\left(\mathrm{H}_{4} \mathrm{~L} 1\right), 1,4-\mathrm{H}_{2} \mathrm{do} 2 \mathrm{p}^{\mathrm{OEt}}\left(\mathrm{H}_{2} \mathrm{~L} 2\right)$, and 1,4- $\mathrm{H}_{2} \mathrm{Bn}_{2} \mathrm{do} 2 \mathrm{p}^{\mathrm{H}}$ $\left(\mathrm{H}_{2} \mathrm{~L} 3\right)$ and the stability constants of their complexes with selected metal ions were determined by standard potentiometric titrations. A full set of the experimental values (with standard deviations) is outlined in the Supporting Information (Table S2).

The protonation constants of the ligands are listed in Table 1. Their values indicate that the phosphonate derivative, $1,4-\mathrm{H}_{4} \mathrm{do} 2 \mathrm{p}$, has the highest ring amine group basicity among the ligands except the first $\mathrm{H}_{4}$ dota constant [41]. The values of 1,4- $\mathrm{H}_{4} \mathrm{do} 2 \mathrm{p}$ are similar to those of its isomer, $1,7-\mathrm{H}_{4} \mathrm{do} 2 \mathrm{p}$ [34]. It is expectable as the doubly negatively charged phosphonate groups exhibit $+I$ effect and it has been previously observed for other ligands with phosphonate pendant arms [42]. In addition, the ring amine group basicity can be also increased due to a strong hydrogen bond between the amine group(s) and the pendant arm [39]. On the other hand, deprotonated phosphonate-monoester and phosphinate groups having $-I$ effect decrease basicity of the neighboring ring amine groups, and they do not form strong intramolecular hydrogen bonds with the protonated amine groups [42]. Consequently, the first protonation constants, $\log K_{\mathrm{H} 1}$, of $1,4-\mathrm{H}_{2} \mathrm{do} 2 \mathrm{p}^{\mathrm{OEt}}$, 1,4- $\mathrm{H}_{2} \mathrm{Bn}_{2} \mathrm{do} 2 \mathrm{p}^{\mathrm{H}}$, and the related 1,7- $\mathrm{H}_{2} \mathrm{do} 2 \mathrm{p}^{\mathrm{OEt}}$ [34] are more than one order of magnitude lower than the corresponding values for the phosphonate derivatives. The second protonation constants, $\log K_{\mathrm{H} 2}$, of $1,4-\mathrm{H}_{2} \mathrm{do} 2 \mathrm{p}^{\mathrm{OEt}}$ and $1,4-\mathrm{H}_{2} \mathrm{Bn}_{2} \mathrm{do} 2 \mathrm{p}^{\mathrm{H}}$ are lower than those found for the acetate derivatives and the lowest value was found for $1,4-\mathrm{H}_{2} \mathrm{Bn}_{2} \mathrm{do} 2 \mathrm{p}^{\mathrm{H}}$ containing $N$-benzyl groups which further decrease basicity of the amine groups. The third and fourth protonation constants of $1,4-\mathrm{H}_{4} \mathrm{do} 2 \mathrm{p}$ obviously correspond to the second protonation step of the phosphonate pendant moieties and the values are similar to those of its 1,7-isomer [34]. Values of these constants lie in the range of values commonly found for the groups [42-45]. For 1,4- $\mathrm{H}_{4} \mathrm{do} 2 \mathrm{p}$ and, 1,4- $\mathrm{H}_{2} \mathrm{do} 2 \mathrm{p}^{\mathrm{OEt}}$, the other protonations occurring in a strong acid region ( $\log K_{\mathrm{H} 5}$ and $\log K_{\mathrm{H} 3}$, respectively) were found. They could be assigned to protonation of 
the pendant arm or further protonation of the macrocycle amino groups. Ligand distribution diagrams are shown in Figure S2.

Table 1. Stepwise protonation constants ${ }^{a}$ of $1,4-\mathrm{H}_{4} \mathrm{do} 2 \mathrm{p}, 1,4-\mathrm{H}_{2} \mathrm{do} 2 \mathrm{p}^{\mathrm{OEt}}$, and $1,4-\mathrm{H}_{2} \mathrm{Bn}_{2} \mathrm{do} 2 \mathrm{p}^{\mathrm{H}}$ and other ligands discussed in the text $\left(25^{\circ} \mathrm{C}, I=0.1 \mathrm{M}\right)$.

\begin{tabular}{|c|c|c|c|c|c|}
\hline Ligand & $\log K_{\mathrm{H} 1}$ & $\log K_{\mathrm{H} 2}$ & $\log K_{\mathrm{H} 3}$ & $\log K_{\mathrm{H} 4}$ & $\log K_{\mathrm{H} 5}$ \\
\hline $1,4-\mathrm{H}_{4} \mathrm{do} 2 \mathrm{p}$ & 12.84 & 11.20 & 7.75 & 4.94 & 1.40 \\
\hline $1,7-\mathrm{H}_{4} \mathrm{do} 2 \mathrm{p}[34]$ & 12.80 & 10.92 & 8.47 & 6.39 & $-b$ \\
\hline $1,4-\mathrm{H}_{2} \mathrm{do} 2 \mathrm{p}^{\mathrm{OEt}}$ & 11.38 & 8.57 & 1.29 & $--^{c}$ & $-{ }^{c}$ \\
\hline $1,7-\mathrm{H}_{2} \mathrm{do} 2 \mathrm{p}^{\mathrm{OEt}}[34]$ & 11.14 & 8.94 & $-b$ & $-b$ & $-b$ \\
\hline $1,4-\mathrm{H}_{2} \mathrm{Bn}_{2} \mathrm{do} 2 \mathrm{p}^{\mathrm{H}}$ & 11.22 & 6.78 & $--^{c}$ & $--^{c}$ & $--^{c}$ \\
\hline $\mathrm{H}_{4}$ dota [41] & 12.90 & 9.76 & 4.68 & 4.11 & 2.37 \\
\hline 1,4-H $\mathrm{H}_{2}$ do2a [29] & 11.07 & 9.76 & 3.84 & 1.75 & $-b$ \\
\hline 1,7-H $\mathrm{H}_{2} \mathrm{do} 2 \mathrm{a}[28]$ & 10.91 & 9.45 & 4.09 & 3.18 & $-{ }^{b}$ \\
\hline
\end{tabular}

${ }^{a}$ Defined as $K_{\mathrm{H} i}=\left[\mathrm{H}_{i} \mathrm{~L}\right] /\left([\mathrm{H}] \cdot\left[\mathrm{H}_{i-1} \mathrm{~L}\right]\right)$ for $i=1-5$ (charges are omitted for clarity). ${ }^{b}$ Not reported. ${ }^{c}$ Not determined.

Stability constants of the metal complexes are given in Table 2, and representative distribution diagrams of selected ligand-metal ion systems are shown in Figure 3 and Figures S3-S4. The stability constants of the title ligands with studied transition metal ions, $\mathrm{Mn}(\mathrm{II}), \mathrm{Cu}(\mathrm{II})$, and $\mathrm{Zn}(\mathrm{II})$, abide the Irving-Williams order and the ligands are very selective for the $\mathrm{Cu}(\mathrm{II})$ ion (about five orders of magnitude) over $\mathrm{Zn}(\mathrm{II})$ ion. This selectivity together with a high stability of the $\mathrm{Cu}(\mathrm{II})$ complexes (quantitative complex formation at $\mathrm{pH} \sim 3-4$, Figure S3) suggests that the ligands are potentially useful for radiopharmaceuticals employing copper radioisotopes. Another notable difference arises from comparison of stability of $\mathrm{Mn}$ (II) and $\mathrm{Ca}$ (II) complexes. The studied ligands strongly prefer complexation with $\mathrm{Mn}(\mathrm{II})$ (about six orders of magnitude higher values for $\mathrm{Mn}(\mathrm{II})$ ). However, $\mathrm{Mn}(\mathrm{II})$ is fully complexed only at $\mathrm{pH} \sim 8$ (Figure $3 \mathrm{~A}-\mathrm{C}$ ) and, thus, the complexes cannot be used in vivo.

Table 2. Stability and protonation constants of $1,4-\mathrm{H}_{4} \mathrm{do} 2 \mathrm{p}, 1,4-\mathrm{H}_{2} \mathrm{do} 2 \mathrm{p}^{\mathrm{OEt}}$, and $1,4-\mathrm{H}_{2} \mathrm{Bn}_{2} \mathrm{do} 2 \mathrm{p}^{\mathrm{H}}$ complexes with selected metal ions $\left(25^{\circ} \mathrm{C}, I=0.1 \mathrm{M} \mathrm{NMe}{ }_{4} \mathrm{Cl}\right)$.

\begin{tabular}{|c|c|c|c|c|c|c|}
\hline \multirow{2}{*}{ Constant } & Mg(II) & $\mathrm{Ca}(\mathrm{II})$ & Mn(II) & $\mathrm{Cu}(\mathrm{II})$ & $\mathrm{Zn}(\mathrm{II})$ & Gd(III) \\
\hline & \multicolumn{6}{|c|}{$1,4-\mathrm{H}_{4} \mathrm{do} 2 \mathrm{p}$} \\
\hline $\log K_{\mathrm{LM}}{ }^{a}$ & 7.36 & 9.29 & 15.41 & 26.45 & 21.11 & 19.15 \\
\hline $\log K_{\mathrm{HLM}}{ }^{b}$ & 9.71 & 9.02 & 8.1 & 6.68 & 6.89 & 7.05 \\
\hline $\log K_{\mathrm{H} 2 \mathrm{LM}}{ }^{b}$ & 9.24 & $--^{c}$ & 5.24 & 4.67 & 4.11 & 6.02 \\
\hline $\log K_{\mathrm{H} 3 \mathrm{LM}}{ }^{b}$ & $-{ }^{c}$ & $-{ }^{c}$ & $-{ }^{c}$ & $-{ }^{c}$ & $-{ }^{c}$ & 3.86 \\
\hline $\log K_{\mathrm{LM}(\mathrm{OH})}{ }^{d}$ & $-{ }^{c}$ & $-{ }^{c}$ & $--^{c}$ & $-{ }^{c}$ & 12.81 & $-{ }^{c}$ \\
\hline \multicolumn{7}{|c|}{$1,4-\mathrm{H}_{2} \mathrm{do} 2 \mathrm{p}^{\mathrm{OEt}}$} \\
\hline $\log K_{\mathrm{LM}}{ }^{a}$ & $-{ }^{c}$ & 5.9 & 11.42 & 19.55 & 15.42 & $-{ }^{c}$ \\
\hline $\log K_{\mathrm{LM}(\mathrm{OH})}{ }^{d}$ & $-{ }^{c}$ & $-{ }^{c}$ & 12.2 & 12.71 & 9.51 & $-{ }^{c}$ \\
\hline \multicolumn{7}{|c|}{$1,4-\mathrm{H}_{2} \mathrm{Bn}_{2} \mathrm{do} 2 \mathrm{p}^{\mathrm{H}}$} \\
\hline $\log K_{\mathrm{LM}}{ }^{a}$ & $-{ }^{c}$ & 3.96 & 9.39 & $-c$ & 13.26 & $-{ }^{c}$ \\
\hline $\log K_{\mathrm{LM}(\mathrm{OH})} d$ & $-{ }^{c}$ & 12.28 & 11.13 & $-{ }^{c}$ & 9.12 & $-{ }^{c}$ \\
\hline $\log K_{\mathrm{LM}(\mathrm{OH}) 2^{d}}$ & $-{ }^{c}$ & $-{ }^{c}$ & $-{ }^{c}$ & $-{ }^{c}$ & 17.29 & $-{ }^{c}$ \\
\hline
\end{tabular}

The $\mathrm{Mg}(\mathrm{II})$ complexation was observed only for $1,4-\mathrm{H}_{4} \mathrm{do} 2 \mathrm{p}$; for the other two ligands, the complexes are too weak and precipitation of the metal hydroxide occurred in the neutral region. The 1,4- $\mathrm{H}_{4}$ do2p showed a relatively high stability of its $\mathrm{Gd}(\mathrm{III})$ complex $\left(\log K_{\mathrm{LM}}=19.15\right)$ resulting in the full complex formation at $\mathrm{pH} \sim 6$ (Figure 3D). In the systems with the other two ligands, gadolinium(III) hydroxide precipitated before the complex formation. The stability constant of Gd(III) 
complex with hexadentate 1,4- $\mathrm{H}_{4} \mathrm{do} 2 \mathrm{p}\left(\log K_{\mathrm{LM}}=19.15\right)$ is lower than those of heptadentate $\mathrm{H}_{3}$ do3a $\left(\log K_{\mathrm{LM}}=21.0\right)$ [46] or $\mathrm{H}_{6} \operatorname{do3} \mathrm{p}\left(\log K_{\mathrm{LM}}=24.6\right)$ [43]. It is a result of the higher denticity and basicity of these heptadentate ligands. Comparing with isomeric ligand $1,7-\mathrm{H}_{4} \mathrm{do} 2 \mathrm{p}\left(\log K_{\mathrm{LM}}=18.2\right)$ [34], the stability of the 1,4-isomer complex is higher, probably due to the presence of a formally "ethylenediamine-like" motif with two closely located phosphonate groups.
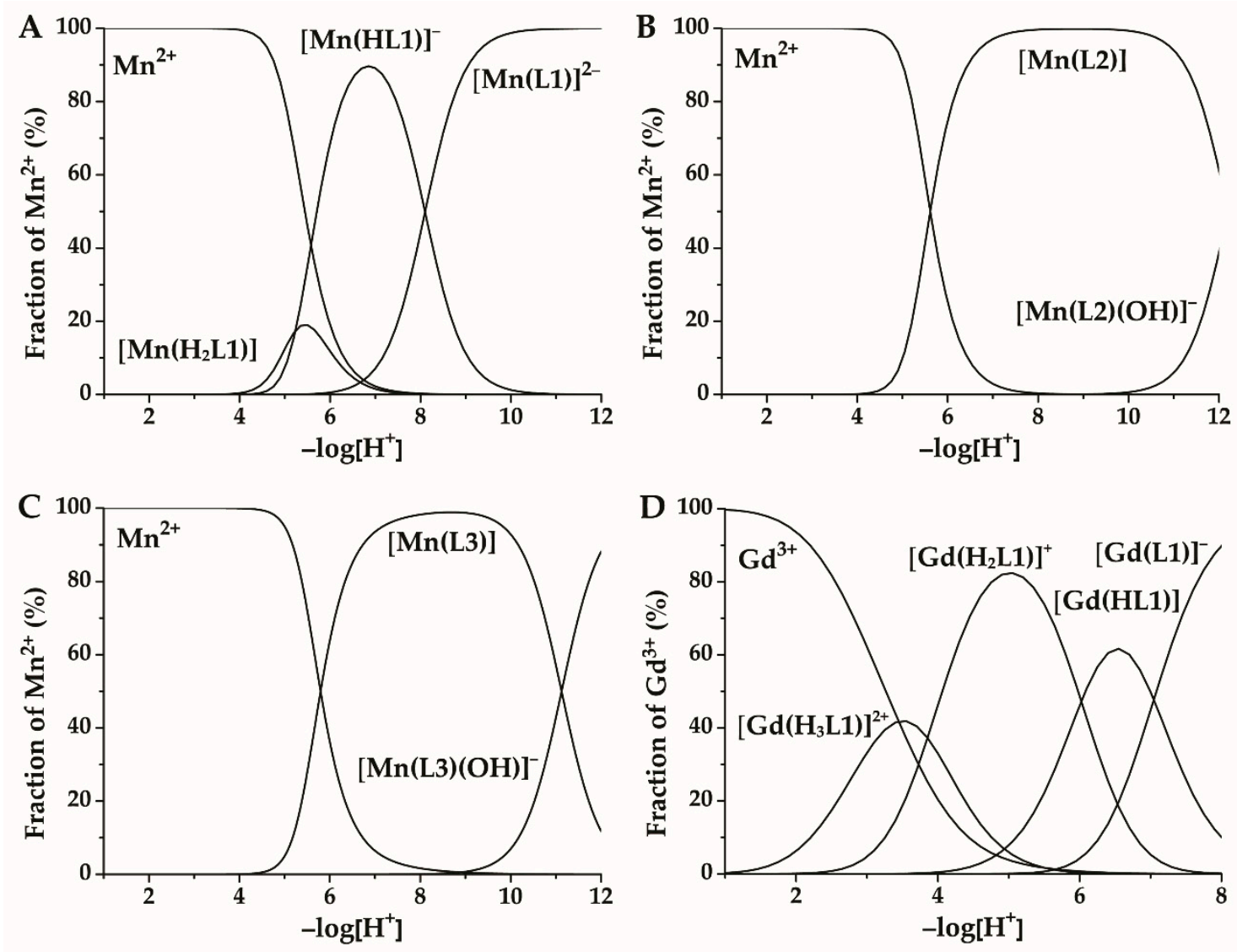

Figure 3. Species distribution diagrams of A: $\mathrm{Mn}(\mathrm{II})-1,4-\mathrm{H}_{4} \mathrm{do} 2 \mathrm{p}\left(\mathrm{H}_{4} \mathrm{~L} 1\right) ; \mathbf{B}: \mathrm{Mn}(\mathrm{II})-1,4-\mathrm{H}_{2} \mathrm{do} 2 \mathrm{p}^{\mathrm{OEt}}$ $\left(\mathrm{H}_{2} \mathrm{~L} 2\right) ; \mathrm{C}: \mathrm{Mn}(\mathrm{II})-1,4-\mathrm{H}_{2} \mathrm{Bn}_{2} \mathrm{do} 2 \mathrm{p}^{\mathrm{H}}\left(\mathrm{H}_{2} \mathrm{~L} 3\right)$; and D: Gd(III)-1,4- $\mathrm{H}_{4} \mathrm{do} 2 \mathrm{p}\left(\mathrm{H}_{4} \mathrm{~L} 1\right)$ systems $\left(\mathrm{C}_{\mathrm{M}}=\mathrm{C}_{\mathrm{L}}=5\right.$ $\left.\mathrm{mM}, I=0.1 \mathrm{M} \mathrm{NMe}_{4} \mathrm{Cl}, 25^{\circ} \mathrm{C}\right)$.

However, a direct comparison of values of the stability constants is misleading as the ligands have different proton affinities (protonation of the donor sites is competing process to the complexation of metal ions). Therefore, concentrations of the free metal ions in the solutions with M:L molar ratio 1:1 $\left(C_{L}=C_{M}=0.001 \mathrm{M}\right)$ at physiological $\mathrm{pH}$ were calculated, and the values are given in Table 3 together with the literature data for other ligands obtained under similar conditions.

The stability of the $\mathrm{Gd}(\mathrm{III})-1,4-\mathrm{H}_{4} \mathrm{do} 2 \mathrm{p}$ complex is slightly higher than the that of the complex of the 1,7-isomer [34]. However, it should be noted, that the thermodynamically sufficiently stable $\mathrm{Gd}(\mathrm{III})-\mathrm{H}_{3}$ do3a complex, showing a pGd value almost three orders of magnitude higher than that for the $\mathrm{Gd}(\mathrm{III})-1,4-\mathrm{H}_{4}$ do2p complex (Table 3), is not sufficiently kinetically inert to be used in vivo [50,51]. Among Mn(II) complexes with hexadentate ligands, complexes of the acetate derivatives exhibit better thermodynamic stability at neutral $\mathrm{pH}$. However, all complexes show a low relaxivity due to their poor hydration ( $q<1$, see below) [31] and, mostly, they have insufficient stability as full complexation is reached at $\mathrm{pH}$ higher than the physiological one [32-34]. Increase in stability can be realized with more coordinating pendant arms (i.e., with the ligand having seven or eight donor atoms, e.g., $\mathrm{H}_{3}$ do3a and $\mathrm{H}_{4}$ dota). Although all donor groups of such ligands are not utilized for the metal ion coordination, stability of their complexes steeply increases as the pendant arms are probably fluxional exchanging 
coordinated/uncoordinated pendant groups and, thus, easily keep metal ion hexa- $\left(\mathrm{N}_{4} \mathrm{O}_{2}\right)$ coordinated in the ligand cavity.

Table 3. Comparison of stability constants of $\mathrm{Cu}(\mathrm{II}), \mathrm{Mn}(\mathrm{II})$, and $\mathrm{Gd}(\mathrm{III})$ complexes with 1,4- $\mathrm{H}_{4} \mathrm{do} 2 \mathrm{p}$ and related ligands, and calculated concentrations of the free metal ion ( $\mathrm{pM}=-\log [\mathrm{M}])$ for $\mathrm{C}_{\mathrm{L}}=\mathrm{C}_{\mathrm{M}}=0.001 \mathrm{M}$ and $\mathrm{pH}=7.4$.

\begin{tabular}{|c|c|c|c|c|c|c|}
\hline Ligand & $\log K(\mathrm{CuL})$ & $\log K(\mathrm{MnL})$ & $\log K(\mathrm{GdL})$ & $\mathrm{pCu}$ & pMn & pGd \\
\hline 1,4- $\mathrm{H}_{4} \mathrm{do} 2 \mathrm{p}$ & 26.45 & 15.41 & 19.15 & 9.9 & 4.7 & 6.3 \\
\hline $1,4-\mathrm{H}_{2} \mathrm{do} 2 \mathrm{p}$ OEt & 19.55 & 11.42 & $-a$ & 8.9 & 4.6 & $-b$ \\
\hline $1,4-\mathrm{H}_{2} \mathrm{Bn}_{2} \mathrm{do} 2 \mathrm{p}^{\mathrm{H}}$ & $-a$ & 9.39 & $-{ }^{a}$ & $-b$ & 4.2 & $-b$ \\
\hline $1,7-\mathrm{H}_{4} \mathrm{do} 2 \mathrm{p}[34,36]$ & 28.7 & 18.1 & 18.2 & 10.8 & 5.5 & 6.0 \\
\hline $1,7-\mathrm{H}_{2} \mathrm{do} 2 \mathrm{p}^{\mathrm{OEt}}[34]$ & $-c$ & 11.03 & 9.81 & $-b$ & 4.4 & 3.8 \\
\hline $1,4-\mathrm{H}_{2}$ do $2 \mathrm{a}[29,33]$ & 24.43 & 16.13 & $-c$ & 10.6 & 6.6 & $-b$ \\
\hline $1,7-\mathrm{H}_{2} \mathrm{do} 2 \mathrm{a}[29,33]$ & 24.24 & 14.54 & $19.1-19.4$ & 10.3 & 5.6 & $8.0-8.4$ \\
\hline $\mathrm{H}_{3}$ do3a $[29,33,46-49]$ & 25.75 & $19.40-19.43$ & $21.0-22.02$ & 11.0 & $7.8-8.3$ & $9.0-9.1$ \\
\hline $\mathrm{H}_{4}$ dota $[28,29,33,48,49]$ & 24.83 & $19.33-19.89$ & 24.67 & 10.7 & $7.9-8.1$ & 10.5 \\
\hline
\end{tabular}

Generally, investigation of the thermodynamic properties of the title ligands and their complexes fill up the gap in knowledge of such macrocyclic systems, and the data follows the expected trends [42].

\subsection{Hydration Number of $M n(I I)$ and Gd(III) Complexes}

A key parameter for MRI applications of paramagnetic complexes is undoubtedly a number of directly coordinated water molecules [52]. Although the $\mathrm{Mn}$ (II) and Gd(III) complexes of the studied ligands do not show sufficient stability for in vivo applications, determination of hydration of the complex species will shed some light on their molecular structure in solution and will bring potentially useful information for a design of better ligands having a higher denticity (and expected higher stability). Therefore, relaxometric data were acquired for the $\mathrm{Gd}(\mathrm{III})-1,4-\mathrm{H}_{4} \mathrm{do} 2 \mathrm{p}$ system and for $\mathrm{Mn}$ (II) complexes of all studied ligands. The efficiency of a paramagnetic contrast agent is commonly described by proton relaxivity, $r_{1}$. It is mostly determined by a measurement of relaxation enhancement of water protons in the presence of paramagnetics in the solution at various external magnetic fields. The resulting ${ }^{1} \mathrm{H}$ NMRD (nuclear magnetic relaxation dispersion) profiles are influenced by some microscopic parameters governing the relaxivity. The shape of the ${ }^{1} \mathrm{H}$ NMRD profile depends on a combination of several physico-chemical parameters and can help to estimate some MRI-related properties of the paramagnetic complexes in solution. Graphical representations of obtained data are shown in Figure 4 and Figure S5, and proton relaxivity data are summarized in Table 4 together with comparison with related systems.

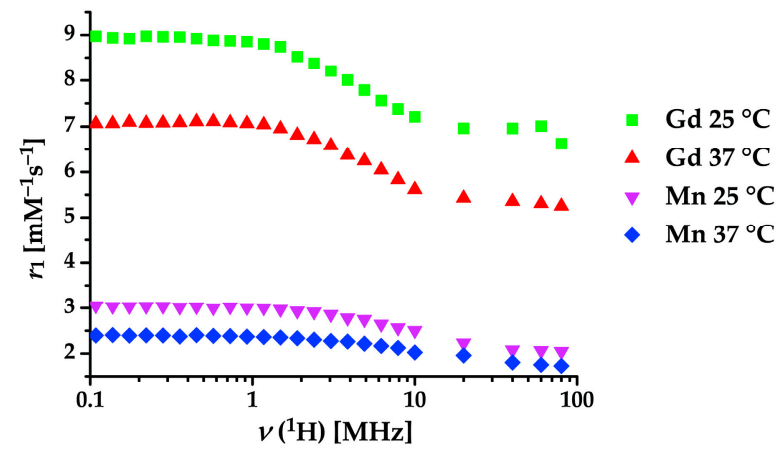

Figure 4. ${ }^{1} \mathrm{H}$ NMRD profiles of Mn(II)-1,4- $\mathrm{H}_{4} \mathrm{do} 2 \mathrm{p}\left(\mathrm{pH} 9.5, \sim 100 \%[\mathrm{Mn}(1,4-\mathrm{do} 2 \mathrm{p})]^{2-}\right)$ and $\mathrm{Gd}(\mathrm{III})-1,4-\mathrm{H}_{4} \mathrm{do} p \mathrm{p}$ $\left(\mathrm{pH} 8.5, \sim 100 \%\left[\mathrm{Gd}\left(\mathrm{H}_{2} \mathrm{O}\right)_{x}(1,4-\mathrm{do} 2 \mathrm{p})\right]^{-}\right)$systems. 
The ${ }^{1} \mathrm{H}$ NMRD profiles measured for Mn(II)-1,4- $\mathrm{H}_{4} \mathrm{do} 2 \mathrm{p}$ and $\mathrm{Gd}(\mathrm{III})-1,4-\mathrm{H}_{4} \mathrm{do} 2 \mathrm{p}$ systems at 25 and $37^{\circ} \mathrm{C}$ are typical for low-molecular-weight paramagnetic chelates, showing a single dispersion between 1 and $10 \mathrm{MHz}$ (Figure 4). In the case of the $\mathrm{Mn}(\mathrm{II})-1,4-\mathrm{H}_{4} \mathrm{do} 2 \mathrm{p}$ complex, absence of the second dispersion at low field clearly shows $[7,8,53]$ that no free aqua $\mathrm{Mn}(\mathrm{II})$ ion is present in the solution as suggested from the distribution diagram (Figure 3). Ligands denticities (6) and the usual coordination number of Mn(II) ions (6-7) allow for a possible hydration number in a range of $q$ 0-1 in these systems. The relaxivity values of the Mn(II) complexes (Figure 4 and Figure S5, Table 4) at high fields are low (in the range of $r_{1}$ 1-2 $\mathrm{mm}^{-1} \mathrm{~s}^{-1}$ ) which points to a fact that no directly $\mathrm{Mn}$ (II)-coordinated water molecule is present $(q=0)$ [30]. Then, such a small relaxivity can be attributed to the second- and/or outer-sphere contributions.

Table 4. Comparison of proton relaxivity, denticity, and hydration number $q$ for complexes with the title and similar ligands, and for hydrated "free" metal ions $\left(37^{\circ} \mathrm{C}, 20 \mathrm{MHz}\right)$.

\begin{tabular}{|c|c|c|c|}
\hline Complex & $\begin{array}{c}r_{1}\left({ }^{1} \mathrm{H}\right)[9,10,30,31,54] \\
\mathrm{mm}^{-1} \mathrm{~s}^{-1} \text { at } 20 \mathrm{MHz} \text { and } 37^{\circ} \mathrm{C}\end{array}$ & Denticity & $q[3,52]$ \\
\hline$[\mathrm{Mn}(1,4-\mathrm{do} 2 \mathrm{p})]^{2-}$ & 1.96 & 6 & 0 \\
\hline$\left[\mathrm{Mn}\left(1,4-\mathrm{do} 2 \mathrm{p}^{\mathrm{OEt}}\right)\right]$ & 2.00 & 6 & 0 \\
\hline$\left[\mathrm{Mn}\left(\mathrm{Bn}_{2} \mathrm{do} 2 \mathrm{p}^{\mathrm{H}}\right)\right]$ & 1.37 & 6 & 0 \\
\hline$\left[\mathrm{Mn}\left(\mathrm{H}_{2} \mathrm{O}\right)_{6}\right]^{2+}$ & 6.76 & $-{ }^{a}$ & 6 \\
\hline$[\mathrm{Mn}(\text { dota })]^{2-}$ & 3.20 & $6^{b}$ & 0 \\
\hline$[\mathrm{Mn}(\text { edta })]^{2-}$ & 3.30 & 6 & 1 \\
\hline$[\mathrm{Mn}(\mathrm{do} 3 \mathrm{a})]^{-}$ & 1.3 & 7 & 0 \\
\hline$[\mathrm{Mn}(1,7-\mathrm{do} 2 \mathrm{a})]$ & $1.5^{c}$ & 6 & 0 \\
\hline$[\mathrm{Mn}(1,4-\mathrm{do} 2 \mathrm{a})]$ & 2.1 & 6 & $0-1$ \\
\hline$[\mathrm{Gd}(1,4-\mathrm{do} 2 \mathrm{p})]^{-}$ & 5.42 & 6 & $1-2$ \\
\hline [Gd(do3a)] & 4.80 & 7 & 2 \\
\hline$[\mathrm{Gd}(\text { dota })]^{-}$ & 3.56 & 8 & 1 \\
\hline$\left[\mathrm{Gd}\left(\mathrm{H}_{2} \mathrm{O}\right)_{8}\right]^{3+}$ & 10.5 & $-{ }^{a}$ & 8 \\
\hline
\end{tabular}

\footnotetext{
${ }^{a}$ Non-relevant. ${ }^{b}$ In the $\mathrm{Mn}(\mathrm{II})$ complex, $\mathrm{H}_{2}$ dota $^{2-}$ behaves as a hexadentate anion [54]. ${ }^{c}$ Contradictory results are reported in literature $[20,54]$, and, therefore, a value consistent with those found for analogous systems is presented here.
}

Contrarily, the relaxivity (Figure 4, Table 4) exhibited by the Gd(III)-1,4- $\mathrm{H}_{4} \mathrm{do} 2 \mathrm{p}$ system hints at a higher hydration number of the complex. According to the hexadentate nature of $1,4-\mathrm{H}_{4} \mathrm{do} 2 \mathrm{p}$ and common coordination numbers of Gd(III) ions (8-9), one would expect up to 2-3 directly coordinated water molecules to the metal centre. Considering a relatively high steric hindrance of the phosphonate groups [55], the hydration probably cannot be reached. In addition, the relaxivity value (Table 4) is not high enough to justify the presence of three directly bound water molecules, as relaxivity is only slightly higher than that for $\left[\mathrm{Gd}\left(\mathrm{H}_{2} \mathrm{O}\right)_{2}(\mathrm{do} 3 \mathrm{a})\right]$ which binds two water molecules in the inner sphere [56]. Due to high hydrophilicity of the phosphonate groups, it can be suggested that some part of the overall relaxivity of the $\mathrm{Gd}(\mathrm{III})-1,4-\mathrm{H}_{4} \mathrm{do} 2 \mathrm{p}$ complex can be attributed to a second-sphere contributions and, then, $q=1-2$ can be expected for the system. Anyway, hydration equilibrium with $q=2-3$ cannot be fully excluded as not fully convincing hydration data were reported for the $\mathrm{Ln}(\mathrm{III})-1,7-\mathrm{H}_{4}$ do2p complexes [57].

To obtain a more reliable value of $q$, the hydration state of the central $\mathrm{Ln}$ (III) ions in the Eu(III) and $\mathrm{Tb}(\mathrm{III})$ complexes was probed using luminescence lifetime measurements as the lifetimes are sensitive to the presence of an $\mathrm{O}-\mathrm{H}$ bond(s) as a vibrational quencher [58-60]. Lifetimes of the $\mathrm{Eu}(\mathrm{III}) / \mathrm{Tb}$ (III)-1,4- $\mathrm{H}_{4}$ do2 $\mathrm{p}$ systems measured in $\mathrm{H}_{2} \mathrm{O}$ and $\mathrm{D}_{2} \mathrm{O}$ are outlined in Table 5 . From the data, the hydration number can be elucidated by well-established empirical formulas [58-60]. Thus, the break in hydration occurs at around Gd(III) and $q$ should be in the range of $1-2$ in the Gd(III)-1,4- $\mathrm{H}_{4} \mathrm{do} 2 \mathrm{p}$ complex and it is consistent with the above suggestion based on the proton relaxivity values. 
To solve the "hydration" problem, absorption spectra of the ${ }^{5} \mathrm{D}_{0} \leftarrow{ }^{7} \mathrm{~F}_{0}$ transition for the $\mathrm{Eu}(\mathrm{III})-1,4-\mathrm{H}_{4} \mathrm{do} 2 \mathrm{p}$ complex were recorded at various temperatures. Since the transition is extremely sensitive to local coordination environment of the central $\mathrm{Eu}(\mathrm{III})$ ion, any change in hydration (i.e., in a coordination number) results in appearance of two spectral bands with peak separation larger than $0.5 \mathrm{~nm}[56,61]$. Two peaks (Figure 5) with separation $\sim 0.6 \mathrm{~nm}$ were observed pointing to a presence of two distinct species with the different hydration states. Abundance of each species can be determined by deconvolution (Table 6) of the absorption spectra. In general, the species with a higher hydration number is preferred at low temperature whereas increase in temperature leads to species with a lower $q$ [56]. Based on the emission absorption data, it can be concluded that two species present in solution are $\left[\mathrm{Eu}(1,4-\mathrm{do} 2 \mathrm{p})\left(\mathrm{H}_{2} \mathrm{O}\right)\right]^{-}$and $\left[\mathrm{Eu}(1,4-\mathrm{do} 2 \mathrm{p})\left(\mathrm{H}_{2} \mathrm{O}\right)_{2}\right]^{-}$complexes, with a high preference for the bis(hydrated) species at room temperature. Therefore, the $\left[\mathrm{Gd}(1,4-\mathrm{do} 2 \mathrm{p})\left(\mathrm{H}_{2} \mathrm{O}\right)_{1-2}\right]^{-}$equilibrium can be expected to take place in solution of the $\mathrm{Gd}(\mathrm{III})-1,4-\mathrm{H}_{4} \mathrm{do} 2 \mathrm{p}$ complex.

Table 5. Luminescence lifetimes $\tau_{\mathrm{em}}$ and the corresponding hydration numbers $q$ of the $\mathrm{Eu}(\mathrm{III})$ and $\mathrm{Tb}(\mathrm{III})$ complexes ( $\left.\mathrm{pH} 8.5,25^{\circ} \mathrm{C}\right)$.

\begin{tabular}{|c|c|c|}
\hline Quantity & $\mathrm{Eu}(\mathrm{III})-1,4-\mathrm{H}_{4} \mathrm{do} 2 \mathrm{p}$ & $\mathrm{Tb}(\mathrm{III})-1,4-\mathrm{H}_{4} \mathrm{do} 2 \mathrm{p}$ \\
\hline$\tau_{\mathrm{em}}\left(\mathrm{H}_{2} \mathrm{O}\right) / \mathrm{ms}$ & 0.359 & 2.405 \\
\hline$\tau_{\mathrm{em}}\left(\mathrm{D}_{2} \mathrm{O}\right) / \mathrm{ms}$ & 1.679 & 4.142 \\
\hline$q[58]$ & 2.30 & 0.73 \\
\hline$q[59]$ & 2.33 & 0.57 \\
\hline$q[60]$ & 2.09 & not applicable \\
\hline
\end{tabular}

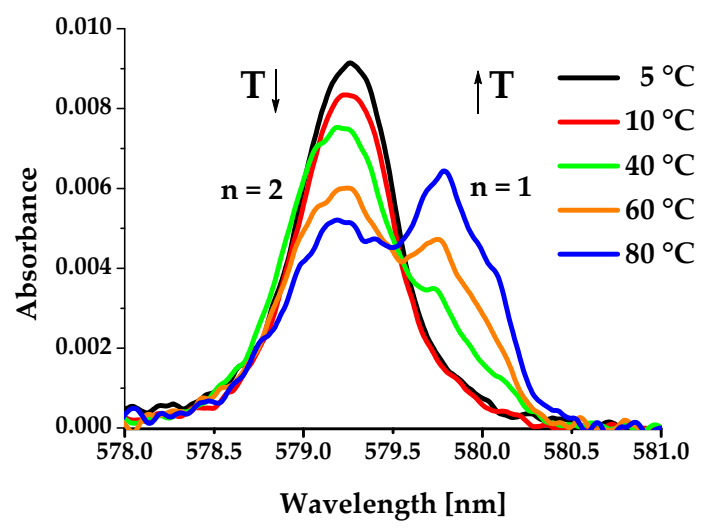

Figure 5. Temperature dependence of ${ }^{5} \mathrm{D}_{0} \leftarrow{ }^{7} \mathrm{~F}_{0}$ transition in absorption spectra of the Eu(III)-1,4- $\mathrm{H}_{4}$ do2p complex ( $\mathrm{pH} 8.5$, selected spectra; for all data, see Figure S6).

Table 6. Species abundance at different temperature according to deconvolution of the absorption spectra of the $\mathrm{Eu}(\mathrm{III})-1,4-\mathrm{H}_{4} \mathrm{do} 2 \mathrm{p}$ complex.

\begin{tabular}{cccccccccc}
\hline \multirow{2}{*}{ Species } & \multicolumn{8}{c}{ Temperature $\left({ }^{\circ} \mathbf{C}\right)$} \\
\cline { 2 - 10 } & $\mathbf{5}$ & $\mathbf{1 0}$ & $\mathbf{2 5}$ & $\mathbf{3 0}$ & $\mathbf{4 0}$ & $\mathbf{5 0}$ & $\mathbf{6 0}$ & $\mathbf{7 0}$ & $\mathbf{8 0}$ \\
\hline$\left[\mathrm{Eu}(1,4-\mathrm{do} 2 \mathrm{p})\left(\mathrm{H}_{2} \mathrm{O}\right)_{2}\right]^{-}(\%)$ & 97.7 & 97.0 & 93.0 & 90.5 & 85.0 & 77.5 & 70.9 & 61.9 & 57.5 \\
{$\left[\mathrm{Eu}(1,4-\mathrm{do} 2 \mathrm{p})\left(\mathrm{H}_{2} \mathrm{O}\right)\right]^{-}(\%)$} & 2.3 & 3.0 & 7.0 & 9.5 & 15.0 & 22.5 & 29.1 & 38.1 & 42.5 \\
\hline
\end{tabular}

\section{Materials and Methods}

Dry solvents were prepared by standard purification procedures [62], distilled under argon, and stored over $4 \AA$ molecular sieves in argon atmosphere: tetrahydrofuran (THF, obtained from Penta, Prague, the Czech Republic, distilled from Na), N,N-dimethylformamide (DMF, obtained from Penta, Prague, the Czech Republic, distilled from $\mathrm{P}_{2} \mathrm{O}_{5}$ ), MeCN (Penta, Prague, the Czech Republic, distilled from $\mathrm{P}_{2} \mathrm{O}_{5}$ ). Other solvents and chemicals were purchased from commercial sources and used as received. 


\subsection{General}

1,4-Dibenzyl-1,4,7,10-tetraazacyclododecane (1) was prepared according to literature [35] with slight modifications made during the scale-up process (for details, see ESI). NMR spectra were recorded at $25{ }^{\circ} \mathrm{C}$ on a VNMRS300 spectrometer (Varian Inc., Palo Alto, CA, USA): ${ }^{1} \mathrm{H} 299.94 \mathrm{MHz}, t-\mathrm{BuOH}$ (internal) $\delta 1.25 \mathrm{ppm}$, TMS (internal) $\delta 0.00 \mathrm{ppm}, \mathrm{CHD}_{2} \mathrm{OD}$ (internal) $\delta 3.31 \mathrm{ppm} ;{ }^{13} \mathrm{C} 75.42 \mathrm{MHz}$, $t$-BuOH (internal) $\delta 30.29$, and $70.36 \mathrm{ppm}$, TMS (internal) $\delta 0.00 \mathrm{ppm}, \mathrm{CHCl}_{3}$ (internal) $\delta 77.00 \mathrm{ppm}$; ${ }^{31} \mathrm{P} 121.4 \mathrm{MHz}, 85 \% \mathrm{H}_{3} \mathrm{PO}_{4}$ in $\mathrm{D}_{2} \mathrm{O}$ (external) $\delta 0.00 \mathrm{ppm}$. Multiplicity of the signals is indicated as follows: $\mathrm{s}$-singlet, $\mathrm{d}$-doublet, $\mathrm{t}$-triplet, $\mathrm{q}-$ quartet, $\mathrm{m}$-multiplet, $\mathrm{br}$-broad. The NMR samples for the compound characterizations were prepared by just dissolving of the compounds in $\mathrm{H}_{2} \mathrm{O} / \mathrm{D}_{2} \mathrm{O}$ and $\mathrm{pH} / \mathrm{pD}$ was not further controlled. Deuterated solvents $\mathrm{D}_{2} \mathrm{O}(99.9 \% \mathrm{D}), \mathrm{CDCl}_{3}(99.8 \% \mathrm{D})$, and $\mathrm{CD}_{3} \mathrm{OD}(99.8 \% \mathrm{D})$ purchased from Chemtrade were used as received. Mass spectra were measured on a spectrometer ESQUIRE 3000 (Bruker, Billerica, MA, USA) equipped with an electro-spray ion source and ion-trap detector in both negative and positive modes. For thin layer chromatography (TLC), aluminum foils with silica gel impregnated with a fluorescent dye were used $\left(60 \mathrm{~F}_{254}\right.$, Merck, Darmstadt, Germany); the compounds were visualized by UV lamp ( $\lambda 254 \mathrm{~nm}$ ), 0.5\% ninhydrin solution in $\mathrm{EtOH}, 5 \%$ aq. copper(II) acetate solution, or iodine vapors. Elemental analyses were done at the Institute of Macromolecular Chemistry (Academy of Science of the Czech Republic, Prague, Czech Republic).

\subsection{Synthesis}

1,4-bis\{[(diethoxy)phosphoryl]methyl\}-7,10-dibenzyl-1,4,7,10-tetraazacyclododecane, 2. 1,4-dibenzyl-1,4,7,10 -tetraazacyclododecane $(\mathbf{1}, 3.30 \mathrm{~g}, 9.38 \mathrm{mmol})$ was dissolved in triethyl phosphite $(25 \mathrm{~mL}, 140 \mathrm{mmol})$, and paraformaldehyde $(1.32 \mathrm{~g}, 37.5 \mathrm{mmol})$ was added. Reaction mixture was heated at $30{ }^{\circ} \mathrm{C}$ and vigorously stirred. Reaction progress was followed by TLC $\left(\mathrm{NH}_{3}: \mathrm{EtOH} 1: 10,1 R_{\mathrm{f}} 0.4 ; 2 R_{\mathrm{f}}\right.$ 0.8 ). When no compound 1 was present on TLC (usually after $24 \mathrm{~h}$ ), the reaction mixture was filtered and loaded on a strong cation exchange resin (Dowex 50, $400 \mathrm{~cm}^{3}, \mathrm{H}^{+}$-cycle, rinsed by EtOH). The triethyl phosphite excess was removed by $\mathrm{EtOH}(700 \mathrm{~mL})$, other impurities were removed by EtOH: $\mathrm{H}_{2} \mathrm{O}(1: 1 \mathrm{v} / \mathrm{v}, 700 \mathrm{~mL})$, and the product was eluted by aq. conc. $\mathrm{NH}_{3}: \mathrm{EtOH}(1: 5,1000 \mathrm{~mL})$. The product 2 was isolated as a yellowish oil after evaporation of the solvents $(4.8 \mathrm{~g}, 77 \%$ based on $\mathbf{1})$.

$\mathrm{NMR}\left(\mathrm{CDCl}_{3}\right):{ }^{1} \mathrm{H} \delta 1.29\left(\mathrm{CH}_{3}, 12 \mathrm{H}, \mathrm{t},{ }^{3} J_{\mathrm{HH}}=7.20 \mathrm{~Hz}\right) ; 2.60-2.78\left(\mathrm{~N}_{-}-\mathrm{CH}_{2}-\mathrm{CH}_{2}-\mathrm{N}, 8 \mathrm{H}, \mathrm{br}\right) ; 2.80-3.00$ $\left(\mathrm{N}-\mathrm{CH}_{2}-\mathrm{CH}_{2}-\mathrm{N}, \mathrm{N}-\mathrm{CH}_{2}-\mathrm{P}, 12 \mathrm{H}, \mathrm{br}\right) ; 3.48\left(\mathrm{~N}-\mathrm{CH}_{2}-\mathrm{Ph}, 4 \mathrm{H}, \mathrm{s}\right) ; 4.01\left(\mathrm{O}-\mathrm{CH}_{2}-\mathrm{CH}_{3}, 8 \mathrm{H}, \mathrm{m}\right) ; 7.19-7.30$ (arom, 10H, m); ${ }^{13} \mathrm{C}\left\{{ }^{1} \mathrm{H}\right\} \delta 16.5\left(\mathrm{CH}_{3}, \mathrm{~d},{ }^{3} J_{\mathrm{PC}}=5.5 \mathrm{~Hz}\right) ; 50.0\left(\mathrm{~N}-\mathrm{C}-\mathrm{P}, \mathrm{d},{ }^{1} J_{\mathrm{PC}}=153 \mathrm{~Hz}\right) ; 52.2,52.3$, $53.5\left({ }^{3} J_{\mathrm{PC}}=6.8 \mathrm{~Hz}\right)$, and $53.6\left({ }^{3} J_{\mathrm{PC}}=6.8 \mathrm{~Hz}\right)($ all N-C-C-N $) ; 60.1(\mathrm{~N}-\mathrm{C}-\mathrm{Ph}, \mathrm{s}) ; 61.6\left(\mathrm{O}-\mathrm{CH}_{2}-\mathrm{CH}_{3}, \mathrm{~d}\right.$, ${ }^{2} J_{\mathrm{PC}}=7.2 \mathrm{~Hz}$ ); 126.7 (arom.); 128.0 (arom.); 129.1 (arom.); 139.6 (arom., quarternary); ${ }^{31} \mathrm{P}\left\{{ }^{1} \mathrm{H}\right\} \delta 26.1$ (s); ${ }^{31} \mathrm{P} \delta 26.1(\mathrm{~m})$. ESI-MS $\mathrm{m} / z$ (+) found: $653.3(100 \%)$; $654.3(39 \%)$; calcd.: $[\mathrm{M}+\mathrm{H}]^{+}, \mathrm{C}_{32} \mathrm{H}_{55} \mathrm{~N}_{4} \mathrm{O}_{6} \mathrm{P}_{2}{ }^{+}$, including isotopic pattern: $653.4(100 \%)$ and 654.4 (35\%). TLC: conc. aq. $\mathrm{NH}_{3}: \mathrm{EtOH} 1: 10, R_{\mathrm{f}} 0.8$.

1,4-bis\{[(diethoxy)phosphoryl]methyl\}-1,4,7,10-tetraazacyclododecane, 3. Compound 2 (4.7 g, $7.2 \mathrm{mmol})$ was dissolved in aq. acetic acid $(1: 1 \mathrm{v} / \mathrm{v}, 50 \mathrm{~mL})$ and catalyst $(10 \% \mathrm{Pd} / \mathrm{C}, 0.8 \mathrm{~g})$ was added. Balloon with $\mathrm{H}_{2}$ was attached to the flask. Reaction progress was followed by TLC $\left(\mathrm{NH}_{3}: \mathrm{EtOH} 1: 10 ; 2 R_{\mathrm{f}} 0.8 ; 3 R_{\mathrm{f}}\right.$ $0.4)$. After 1 day, the balloon was refilled. Next day, the catalyst was filtered off and the filtrate was co-evaporated with water and afterwards several times with ethanol to remove volatiles. Product (3.2 $\mathrm{g}, 94 \%)$ was isolated as a pale yellow oil.

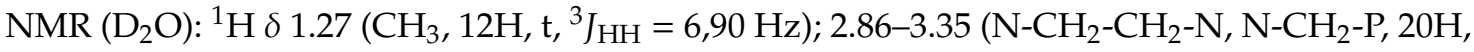

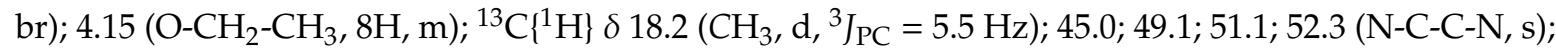
$53.2\left(\mathrm{~N}-\mathrm{CH}_{2}-\mathrm{P}, \mathrm{d},{ }^{1} J_{\mathrm{PC}}=146 \mathrm{~Hz}\right) ; 61.6\left(\mathrm{O}-\mathrm{CH}_{2}-\mathrm{CH}_{3}, \mathrm{~d},{ }^{2} J_{\mathrm{PC}}=7.2 \mathrm{~Hz}\right) .{ }^{31} \mathrm{P}\left\{{ }^{1} \mathrm{H}\right\} \delta 29.7(\mathrm{~s}) ;{ }^{31} \mathrm{P} \delta 29.7(\mathrm{~m})$. ESI-MS m/z (+) found: $473.1(100 \%) ; 474.1(20 \%)$; calcd.: $[\mathrm{M}+\mathrm{H}]^{+}, \mathrm{C}_{18} \mathrm{H}_{43} \mathrm{~N}_{4} \mathrm{O}_{6} \mathrm{P}_{2}{ }^{+}$, including isotopic pattern: $473.3(100 \%)$ and $474.3(20 \%)$. TLC: conc. aq. $\mathrm{NH}_{3}: \mathrm{EtOH} 1: 10, R_{\mathrm{f}} 0.4$; conc. aq. $\mathrm{NH}_{3}: \mathrm{EtOH} 1: 5$, $R_{\mathrm{f}} 0.6$. 
1,4-bis\{[(ethoxy)(hydroxyl)phosphoryl]methyl\}-1,4,7,10-tetraazacyclododecane, 1,4- $\mathrm{H}_{2}$ do2 $\mathrm{p}$ OEt . Compound 3 $(1.3 \mathrm{~g}, 2.0 \mathrm{mmol})$ was dissolved in ethanol $(20 \mathrm{~mL})$ and a solution of $\mathrm{NaOH}(0.4 \mathrm{~g}, 10 \mathrm{mmol})$ in water $(10 \mathrm{~mL})$ was added. Reaction progress was followed by TLC $\left(\mathrm{NH}_{3}: \mathrm{EtOH} 1: 5 ; 3 R_{\mathrm{f}} 0.6 ; 1,4-\mathrm{H}_{2} \mathrm{do} 2 \mathrm{p}\right.$ OEt $\left.R_{\mathrm{f}} 0.3\right)$. After $24 \mathrm{~h}$, reaction mixture was evaporated, the residue was dissolved in water $(5 \mathrm{~mL})$, loaded onto a silica column $(200 \mathrm{~mL})$, and chromatographed with $\mathrm{NH}_{3}: \mathrm{EtOH} 1: 5$. Fractions containing product (TLC check) were combined, evaporated, and loaded onto a weak cation exchange resin (Amberlite 50, $150 \mathrm{~mL}, \mathrm{H}^{+}$-cycle). The column was eluted with water. Fractions containing the pure ligand 1,4- $\mathrm{H}_{2} \mathrm{do} 2 \mathrm{p}^{\mathrm{OEt}}$ were combined and evaporated to a colorless oil which affords a transparent glassy material after lyophilization $(1.02 \mathrm{~g}, 90 \%)$.

$\operatorname{NMR}\left(\mathrm{D}_{2} \mathrm{O}\right):{ }^{1} \mathrm{H} \delta 1.15\left(\mathrm{CH}_{3}, 6 \mathrm{H}, \mathrm{t},{ }^{3} \mathrm{~J}_{\mathrm{HH}}=7.20 \mathrm{~Hz}\right) ; 2.95-3.05\left(\mathrm{~N}-\mathrm{CH}_{2}-\mathrm{CH}_{2}-\mathrm{N}, 7 \mathrm{H}, \mathrm{br}\right) ; 3.05-3.28$ $\left(\mathrm{N}-\mathrm{CH}_{2}-\mathrm{CH}_{2}-\mathrm{N}, \mathrm{N}-\mathrm{CH}_{2}-\mathrm{P}, 13 \mathrm{H}, \mathrm{br}\right) ; 3.88\left(\mathrm{O}-\mathrm{CH}_{2}-\mathrm{CH}_{3}, 4 \mathrm{H}, \mathrm{m}\right) ;{ }^{13} \mathrm{C}\left\{{ }^{1} \mathrm{H}\right\} \delta 18.5\left(\mathrm{CH}_{3}, \mathrm{~d},{ }^{3} J_{\mathrm{PC}}=5.0 \mathrm{~Hz}\right)$; 44.5; 45.8 (N-C-C-N); $51.4\left(\mathrm{~N}-\mathrm{C}-\mathrm{P}, \mathrm{d},{ }^{1} \mathrm{~J}_{\mathrm{PC}}=144 \mathrm{~Hz}\right) ; 53.2 ; 54.3(\mathrm{C}-\mathrm{N}-\mathrm{C}-\mathrm{P}) ; 63.4\left(\mathrm{CH}_{2}-\mathrm{CH}_{3}, \mathrm{~d},{ }^{2} J_{\mathrm{PC}}=6.0 \mathrm{~Hz}\right)$; ${ }^{31} \mathrm{P}\left\{{ }^{1} \mathrm{H}\right\} \delta 17.7(\mathrm{~s}) ;{ }^{31} \mathrm{P} \delta 17.7$ (br); ESI-MS m/z found: (-) $414.9(100 \%) ; 415.8(17 \%) ;(+) 439.0(31 \%) ; 461.0$ (37\%); $477.0(100 \%)$; calc.: (-) $\left[\mathrm{M}-\mathrm{H}^{-}, \mathrm{C}_{14} \mathrm{H}_{33} \mathrm{~N}_{4} \mathrm{O}_{6} \mathrm{P}_{2}{ }^{-}\right.$, including isotopic pattern: $415.2(100 \%)$ and $416.2(15 \%) ;(+)[\mathrm{M}+\mathrm{Na}]^{+}, \mathrm{C}_{14} \mathrm{H}_{34} \mathrm{~N}_{4} \mathrm{NaO}_{6} \mathrm{P}_{2}{ }^{+}: 439.2 ;[\mathrm{M}-\mathrm{H}+2 \mathrm{Na}]^{+}, \mathrm{C}_{14} \mathrm{H}_{33} \mathrm{~N}_{4} \mathrm{Na}_{2} \mathrm{O}_{6} \mathrm{P}_{2}{ }^{+}: 461.2$; $[\mathrm{M}-\mathrm{H}+\mathrm{Na}+\mathrm{K}]^{+}, \mathrm{C}_{14} \mathrm{H}_{33} \mathrm{KN}_{4} \mathrm{NaO}_{6} \mathrm{P}_{2}{ }^{+}$: 477.1. Elem anal.: found (calcd. for 1,4- $\mathrm{H}_{2} \mathrm{do} 2 \mathrm{p}^{\mathrm{OEt}} .4 \mathrm{H}_{2} \mathrm{O}$, $\mathrm{C}_{14} \mathrm{H}_{42} \mathrm{~N}_{4} \mathrm{O}_{10} \mathrm{P}_{2}$ ): C 34.59 (34.43); H 8.72 (8.67); N 11.37 (11.47). TLC: conc. aq. $\mathrm{NH}_{3}: \mathrm{EtOH} 1: 5, R_{\mathrm{f}} 0.3$.

1,4-bis\{[(dihydroxy)phosphoryl]methyl\}-7,10-dibenzyl-1,4,7,10-tetraazacyclododecane, 4 . Compound 2 (2.30 g, $3.53 \mathrm{mmol}$ ) was dissolved in dry MeCN (40 mL) and trimethylsilyl bromide (10.8 g, $70.5 \mathrm{mmol})$ was added. The solution was stirred at room temperature for $18 \mathrm{~h}, \mathrm{MeOH}(20 \mathrm{~mL})$ was added, and solvents were evaporated off in vacuum. The residue was dissolved in $\mathrm{MeOH}(50 \mathrm{~mL})$ and the solvent was evaporated in vacuum, and the co-evaporation with $\mathrm{MeOH}$ was repeated two more times. The crude product was purified on strong cation exchange resin (Dowex 50, $300 \mathrm{~mL}, \mathrm{H}^{+}$-cycle). The column was eluted by water $(1000 \mathrm{~mL})$ followed by conc. aq. $\mathrm{NH}_{3}: \mathrm{EtOH}$ mixture $(1: 5 \mathrm{v} / \mathrm{v}, 700 \mathrm{~mL})$. Product was eluted in the ammonia phase and it was obtained as yellowish powder after evaporation of the solvents (1.80 g) which was directly used in the next step.

NMR $\left(\mathrm{D}_{2} \mathrm{O}\right):{ }^{1} \mathrm{H} \delta 2.95-3.40\left(\mathrm{~N}-\mathrm{CH}_{2}-\mathrm{CH}_{2}-\mathrm{N}, \mathrm{N}-\mathrm{CH}_{2}-\mathrm{P}, 20 \mathrm{H}, \mathrm{br}\right) ; 3.88\left(\mathrm{~N}-\mathrm{CH}_{2}-\mathrm{Ph}, 4 \mathrm{H}, \mathrm{s}\right) ; 7.20-7.40$ (arom., 10H, m); ${ }^{13} \mathrm{C}\left\{{ }^{1} \mathrm{H}\right\} \delta$ 49.3; 51.7 (N-C-C-N); 52.8 (N-C-P, d, $\left.{ }^{1} J_{P C}=153 \mathrm{~Hz}\right) ; 52.9 ; 53.9$ (N-C-C-N); 60.1 (N-C-Ph, s); 131.9 (arom.); 132.3 (arom.); 132.9 (arom.); 133.5 (arom.); ${ }^{31} \mathrm{P}\left\{{ }^{1} \mathrm{H}\right\} \delta 16.9$ (bs); ${ }^{31} \mathrm{P} \delta$ 16.9 (br); ESI-MS m/z found: (-) 539.0 (100\%); 540.0 (24\%); (+) 541.1 (36\%); 563.1 (100\%); 579.1 (68\%); calc.: (-) $[\mathrm{M}-\mathrm{H}]^{-}, \mathrm{C}_{24} \mathrm{H}_{37} \mathrm{~N}_{4} \mathrm{O}_{6} \mathrm{P}_{2}{ }^{-}$, including isotopic pattern: $539.2(100 \%)$ and $540.2(26 \%) ;(+)[\mathrm{M}$ $+\mathrm{H}]^{+}, \mathrm{C}_{24} \mathrm{H}_{39} \mathrm{~N}_{4} \mathrm{O}_{6} \mathrm{P}_{2}{ }^{+}: 541.2 ;[\mathrm{M}+\mathrm{Na}]^{+}, \mathrm{C}_{24} \mathrm{H}_{38} \mathrm{~N}_{4} \mathrm{NaO}_{6} \mathrm{P}_{2}{ }^{+}: 563.2 ;[\mathrm{M}+\mathrm{K}]^{+}, \mathrm{C}_{24} \mathrm{H}_{38} \mathrm{KN}_{4} \mathrm{O}_{6} \mathrm{P}_{2}{ }^{+}$: 579.2. TLC: conc. aq. $\mathrm{NH}_{3}: \mathrm{EtOH} 1: 5, R_{\mathrm{f}} 0.4$.

1,4-bis\{[(dihydroxy)phosphoryl]methyl\}-1,4,7,10-tetraazacyclododecane, 1,4- $\mathrm{H}_{4}$ do2p. Compound 4 (1.8 g, $3.4 \mathrm{mmol})$ was suspended in mixture of toluene $(20 \mathrm{~mL})$ and anhydrous THF $(10 \mathrm{~mL})$ and the solvents were evaporated in vacuum. The pre-dried compound 4 was suspended in anhydrous THF (40 mL) and hexamethyldisilazane $(20 \mathrm{~mL})$ was added. The mixture was heated to reflux for $1 \mathrm{~h}$. The mixture was evaporated to dryness in a flow of dry argon and the residue was dissolved in anhydrous THF $(40 \mathrm{~mL})$. Benzyl chloroformate $(5.0 \mathrm{~g})$ was added and the mixture was stirred for $24 \mathrm{~h}$. Then, mixture of conc. aq. $\mathrm{NH}_{3}(5 \mathrm{~mL})$ and $\mathrm{EtOH}(5 \mathrm{~mL})$ was added and the mixture was stirred for $1 \mathrm{~h}$. The reaction mixture was evaporated to dryness in vacuum, the residue was dissolved in $\mathrm{HBr} / \mathrm{AcOH}(30 \% \mathrm{w} / \mathrm{w})$ mixture and it was stirred at room temperature for $1 \mathrm{~h}$. Afterwards, the mixture was evaporated to dryness, the remaining material was dissolved in water $(30 \mathrm{~mL})$ and the solution was washed three times with $\mathrm{CHCl}_{3}(20 \mathrm{~mL})$. The aqueous phase containing the crude product was purified on strong cation exchange resin (Dowex 50, $300 \mathrm{~mL}, \mathrm{H}^{+}$-cycle). Column was eluted by water $(1000 \mathrm{~mL})$ and $5 \%$ aq. $\mathrm{NH}_{3}(700 \mathrm{~mL})$. The ammonia fraction was evaporated to dryness giving a crude product. It was further purified on a weak cation exchange resin (Amberlite CG50, $300 \mathrm{~mL}, \mathrm{H}^{+}$-cycle) using water as an eluent. Fractions containing pure product were combined and evaporated to dryness. The product, 1,4- $\mathrm{H}_{4} \mathrm{do} 2 \mathrm{p}$, was obtained as a white powder upon evaporation to dryness (1.04 g, 
$87 \%$ over two steps). Single crystals suitable for X-ray diffraction study were obtained upon slow evaporation of aq. solution.

NMR $\left(\mathrm{D}_{2} \mathrm{O}\right):{ }^{1} \mathrm{H} \delta 3.00-3.18\left(\mathrm{~N}-\mathrm{CH}_{2}-\mathrm{CH}_{2}-\mathrm{N}, 12 \mathrm{H}, \mathrm{m}\right) ; 3.24\left(\mathrm{~N}-\mathrm{CH}_{2}-\mathrm{P}, 4 \mathrm{H}, \mathrm{d},{ }^{2} J_{P H}=7.80 \mathrm{~Hz}\right)$; $\left.3.30\left(\mathrm{~N}-\mathrm{CH}_{2}-\mathrm{CH}_{2}-\mathrm{N}, 4 \mathrm{H}, \mathrm{s}\right) ;{ }^{13} \mathrm{C}^{1}{ }^{1} \mathrm{H}\right\} \delta 44.4 ; 45.1(\mathrm{~N}-\mathrm{C}-\mathrm{C}-\mathrm{N}) ; 52.7\left(\mathrm{~N}-\mathrm{C}-\mathrm{P}, \mathrm{d},{ }^{1} J_{P C}=145 \mathrm{~Hz}\right) ; 53.8 ; 53.9$ (C-N-C-P); ${ }^{31} \mathrm{P}\left\{{ }^{1} \mathrm{H}\right\} \delta 16.9$ (bs); ${ }^{31} \mathrm{P} \delta 16.9$ (br m); ESI-MS $\mathrm{m} / \mathrm{z}$ found: (-) 358.7 (100\%); 359.7 (12\%); (+) 360.8 (100\%); 398.8 (28\%); calc.: (-) [M - H] $]^{-}, \mathrm{C}_{10} \mathrm{H}_{25} \mathrm{~N}_{4} \mathrm{O}_{6} \mathrm{P}_{2}{ }^{-}$, including isotopic pattern: 359.1 (100\%) and 360.1 (11\%); (+) [M + H] $]^{+}, \mathrm{C}_{10} \mathrm{H}_{27} \mathrm{~N}_{4} \mathrm{O}_{6} \mathrm{P}_{2}{ }^{+}: 361.1 ;[\mathrm{M}+\mathrm{K}]^{+}, \mathrm{C}_{10} \mathrm{H}_{26} \mathrm{KN}_{4} \mathrm{O}_{6} \mathrm{P}_{2}{ }^{+}: 399.1$. Elem anal.: Found (calcd. for 1,4- $\mathrm{H}_{4}$ do2p.2.5 $\mathrm{H}_{2} \mathrm{O}, \mathrm{C}_{10} \mathrm{H}_{31} \mathrm{~N}_{4} \mathrm{O}_{8.5} \mathrm{P}_{2}$ ): $\mathrm{C} 29.79$ (29.63); $\mathrm{H} 7.13$ (7.71); $\mathrm{N}$ 13.71 (13.82). TLC: ${ }^{i} \mathrm{PrOH}$ : conc. aq. $\mathrm{NH}_{3}: \mathrm{H}_{2} \mathrm{O}$ 7:3:3, $R_{\mathrm{f}} 0.6$.

\section{1,4-dibenzyl-7,10-bis\{[(hydroxyl)(hydrido)phosphoryl]methyl\}-1,4,7,10-tetraazacyclododecane,}

1,4- $\mathrm{H}_{2} \mathrm{Bn}_{2} \mathrm{do} 2 \mathrm{p}^{\mathrm{H}}$. Compound $\mathbf{1}(0.640 \mathrm{~g}, 1.82 \mathrm{mmol})$ was dissolved in mixture of $\mathrm{EtOH}(5 \mathrm{~mL})$ and aq. $\mathrm{HCl}(1: 1,5 \mathrm{~mL})$. Paraformaldehyde $(0.32 \mathrm{~g}, 10.6 \mathrm{mmol})$ and aq. $\mathrm{H}_{3} \mathrm{PO}_{2}(50 \%, 3.8 \mathrm{~mL}, 28.4 \mathrm{mmol})$ were added. The reaction mixture was heated at $50{ }^{\circ} \mathrm{C}$ for $15 \mathrm{~h}$. The mixture was evaporated and the residue was loaded onto a strong cation exchange resin (Dowex 50, $250 \mathrm{~mL}, \mathrm{H}^{+}$-cycle). The column was eluted by water $(1000 \mathrm{~mL})$ and a mixture of aq. conc. $\mathrm{NH}_{3}: \mathrm{EtOH}(1: 5,700 \mathrm{~mL})$. The ammonia phase was evaporated to dryness affording pure product as white powder $(0.77 \mathrm{~g}, 84 \%)$.

NMR $\left(\mathrm{D}_{2} \mathrm{O}\right):{ }^{1} \mathrm{H} \delta 2.60-3.22\left(\mathrm{~N}-\mathrm{CH}_{2}-\mathrm{CH}_{2}-\mathrm{N}, \mathrm{N}-\mathrm{CH}_{2}-\mathrm{P}, 20 \mathrm{H}, \mathrm{m}\right) ; 3.74\left(\mathrm{Ph}_{-} \mathrm{CH}_{2}-\mathrm{N}, 4 \mathrm{H}, \mathrm{s}\right) ; 7.02(\mathrm{P}-\mathrm{H}$, $2 \mathrm{H}$, partly exchanged with the solvent, $\mathrm{d},{ }^{1} J_{P H}=517 \mathrm{~Hz}$ ); $7.12-7.40$ (arom., $10 \mathrm{H}, \mathrm{m}$ ); ${ }^{1}{ }^{1} \mathrm{C}\left\{{ }^{1} \mathrm{H}\right\} \delta 50.6$; $52.2(\mathrm{~N}-\mathrm{C}-\mathrm{C}-\mathrm{N}, \mathrm{s}) ; 52.9\left(\mathrm{C}-\mathrm{N}-\mathrm{C}-\mathrm{P}, \mathrm{d},{ }^{2} J_{P C}=4.5 \mathrm{~Hz}\right) ; 54.4(\mathrm{~N}-\mathrm{C}-\mathrm{C}-\mathrm{N}, \mathrm{s}) ; 56.0\left(\mathrm{~N}-\mathrm{C}-\mathrm{P}, \mathrm{d},{ }^{1} J_{P C}=93 \mathrm{~Hz}\right)$; 59.8 (N-C-Ph); 131.5 (arom.); 131.6 (arom.); 133.3 (arom.); 134.6 (arom., quarternary); ${ }^{31} \mathrm{P}\left\{{ }^{1} \mathrm{H}\right\} \delta 19.6$ (br); ${ }^{31} \mathrm{P} \delta 19.6\left(\mathrm{~d}, \mathrm{br},{ }^{1} J_{P H}=517 \mathrm{~Hz}\right) ;$ ESI-MS m/z found: (-) $507.0(100 \%) ; 507.9$ (30\%); (+) 509.1; 531.1; 553.1; calc.: $(-)\left[\mathrm{M}-\mathrm{H}^{+}\right]^{-}, \mathrm{C}_{24} \mathrm{H}_{37} \mathrm{~N}_{4} \mathrm{O}_{4} \mathrm{P}_{2}{ }^{-}$, including isotopic pattern: $507.2(100 \%)$ and 508.2 $(26 \%) ;(+)[\mathrm{M}+\mathrm{H}]^{+}, \mathrm{C}_{24} \mathrm{H}_{39} \mathrm{~N}_{4} \mathrm{O}_{4} \mathrm{P}_{2}{ }^{+}: 509.2 ;[\mathrm{M}+\mathrm{Na}]^{+}, \mathrm{C}_{24} \mathrm{H}_{38} \mathrm{~N}_{4} \mathrm{NaO}_{4} \mathrm{P}_{2}^{+}: 531.2 ;[\mathrm{M}-\mathrm{H}+2 \mathrm{Na}]^{+}$, $\mathrm{C}_{24} \mathrm{H}_{37} \mathrm{~N}_{4} \mathrm{Na}_{2} \mathrm{O}_{4} \mathrm{P}_{2}{ }^{+}$: 553.2. TLC: conc. aq. $\mathrm{NH}_{3}: \mathrm{EtOH} \mathrm{1:5,} R_{\mathrm{f}} 0.5$.

\subsection{Potentiometric Titrations}

Potentiometric titrations were carried out to determine protonation constants of the ligands and stability constants of their complexes with selected metal ions at 1:1 metal-to-ligand molar ratio. Titrations were performed at $25.0 \pm 0.1{ }^{\circ} \mathrm{C}$ and at an ionic strength of $I=0.1 \mathrm{M}$ (tetramethylammonium chloride) using deionized water. The constant passage of argon saturated with the solvent vapour provided the inert atmosphere. The initial volume in the titration vessel was $\sim 5 \mathrm{~mL}\left(1,4-\mathrm{H}_{4} \mathrm{do} 2 \mathrm{p}\right.$, $\left.1,4-\mathrm{H}_{2} \mathrm{do} 2 \mathrm{p}^{\mathrm{OEt}}\right)$ or $\sim 3 \mathrm{~mL}\left(1,4-\mathrm{H}_{2} \mathrm{Bn}_{2} \mathrm{do} 2 \mathrm{p}^{\mathrm{H}}\right)$. The titrations were performed with tetramethylammonium hydroxide solution $(\sim 0.2 \mathrm{M})$ and at the ligand concentration $\sim 0.004 \mathrm{M}\left(1,4-\mathrm{H}_{4} \mathrm{do} 2 \mathrm{p}, 1,4-\mathrm{H}_{2} \mathrm{do} 2 \mathrm{p}^{\mathrm{OEt}}\right)$ or $\sim 0.003 \mathrm{M}\left(1,4-\mathrm{H}_{2} \mathrm{Bn}_{2} \mathrm{do} 2 \mathrm{p}^{\mathrm{H}}\right)$. For each system, at least three parallel titrations were carried out, each titration consisting of about 50 points. All equilibria were established quickly except the $\mathrm{Gd}^{3+}-1,4-\mathrm{H}_{4} \mathrm{do} 2 \mathrm{p}$ system. In this case, the out-of-cell method was applied using sealed glass ampoules with a waiting time of two weeks for the equilibration.

For the ligand and the ligand-metal ion systems, titrations were run in the $-\log \left[\mathrm{H}^{+}\right]$range 1.7-12.1 and 2.0-11.5 (or until precipitation of the metal hydroxide), respectively, employing a PHM 240 pH-meter, a 2-mL ABU 901 automatic piston burette, and a GK2401B combined electrode (all Radiometer, Copenhagen, Denmark). The OPIUM software package was used for the data treatment $[63,64]$. The value of $\mathrm{p} K_{\mathrm{w}}$ used in calculations was 13.81. Stability constants of the $\mathrm{M}^{2+}-\mathrm{OH}^{-}$systems were taken from literature [65-67]. For more details about potentiometric titrations, see previous papers $[68,69]$. In the following text, $\mathrm{pH}$ will mean $-\log \left[\mathrm{H}^{+}\right]$and the equilibrium constants are concentration constants.

\subsection{Proton Nuclear Magnetic Relaxation Dispersion $\left({ }^{1} H\right.$ NMRD) Measurements}

The ${ }^{1} \mathrm{H}$ NMRD profiles of aq. solutions of the $\mathrm{Mn}(\mathrm{II})$ and $\mathrm{Gd}(\mathrm{III})$ complexes $\left(\mathrm{C}_{\mathrm{MnL}}, \mathrm{C}_{\mathrm{GdL}}=5 \mathrm{~mm}\right)$ with pH 9.5 (Mn(II)-1,4- $\left.\mathrm{H}_{4} \mathrm{do} 2 \mathrm{p}\right), 9.0$ (other Mn(II) complexes), or 8.5 (Gd(III)-1,4- $\mathrm{H}_{4} \mathrm{do} 2 \mathrm{p}$ ) were 
measured at 25 and $37^{\circ} \mathrm{C}$ on a SMARTracer Fast Field-Cycling NMR relaxometer (Stelar, Mede, Italy, 0.00024-0.24 T, 0.01-10 MHz ${ }^{1} \mathrm{H}$ Larmor frequency) and a WP80 NMR electromagnet (Bruker, Billerica, MA, USA) adapted to variable-field measurements $\left(0.47-1.88 \mathrm{~T}, 20-80 \mathrm{MHz}{ }^{1} \mathrm{H}\right.$ Larmor frequency), and controlled by the SMARTracer PC-NMR console. The temperature was controlled by a VTC91 temperature control unit and maintained by a gas flow. The temperature was determined according to previous calibration with a Pt resistance temperature probe.

\subsection{UV-Vis Spectroscopy}

The UV-visible spectra of ${ }^{5} \mathrm{D}_{0} \leftarrow{ }^{7} \mathrm{~F}_{0}$ transitions of the Eu(III)-1,4- $\mathrm{H}_{4}$ do2 $\mathrm{p}$ complex aqueous solution $(0.0185 \mathrm{M}, \mathrm{pH}=8.5)$ were recorded in the temperature range $5-80{ }^{\circ} \mathrm{C}$ on a Perkin-Elmer Lambda 19 spectrometer in thermoregulated cuvette with a 5 -cm optical length $(\lambda=577-581 \mathrm{~nm}$, data steps $0.01 \mathrm{~nm}$ ). Deconvolution of the spectra was done by minimization Excel solver function (Excel 2003, Microsoft, Redmond, WA, USA).

\subsection{Luminescence Spectroscopy}

The luminescence measurements of the $\mathrm{Eu}(\mathrm{III}) / \mathrm{Tb}(\mathrm{III})-1,4-\mathrm{H}_{4} \mathrm{do} 2 \mathrm{p}$ complexes $(0.1 \mathrm{M}, \mathrm{pH} 8.5)$ were performed on a FS900 spectrofluorimeter (Edinburgh Instruments, Livingston, UK), equipped with a $450 \mathrm{~W}$ xenon arc lamp, a microsecond flash lamp, and a red-sensitive photomultiplier (300-850 nm). The luminescence spectra were obtained after excitation at 394 and $352 \mathrm{~nm}$ for the $\mathrm{Eu}(\mathrm{III}) \mathrm{and} \mathrm{Tb}(\mathrm{III})$ complexes, respectively. Emission lifetimes were determined by single-exponential fitting of emission intensity time trace employing peaks at 614 and $545 \mathrm{~nm}$ for the $\mathrm{Eu}(\mathrm{III})$ and $\mathrm{Tb}$ (III) complexes, respectively.

\subsection{Single-Crystal X-Ray Analysis}

Single crystals of 1,4- $\mathrm{H}_{4} \mathrm{do} 2 \mathrm{p} \cdot 4 \mathrm{H}_{2} \mathrm{O}$ were prepared by slow evaporation of the ligand aq. solution in a form of colorless prisms. The diffraction data were collected using a Nonius Kappa CCD diffractometer (Enraf-Nonius, Rotterdam, the Netherlands) at 150(1) K (Cryo-stream Cooler, Oxford Cryosystem, Oxford, UK) using Mo-K $\alpha$ radiation $(\lambda=0.71073 \AA)$ and analyzed using the HKL DENZO program package $[70,71]$. The structure was solved using direct methods and refined by full-matrix least-squares techniques (SHELXS97 [72,73] and SHELXL2014 [74]). Final parameters: triclinic system, space group $P-1, a=7.7439(2) \AA, b=10.7128(3) \AA, c=12.0966(4) \AA, \beta\left(^{\circ}\right)=100.368(1), U=957.24(5) \AA^{3}$, $Z=2,4384$ total refl., 4035 obsd. refl. $(I>2 \sigma(I)), R_{1}=0.0285, w R_{2}=0.0772$, CCDC reference no. 1943113. All non-hydrogen atoms were refined anisotropically. The hydrogen atoms were located in the electron density map, however; those belonging to the carbon atoms were fixed in the theoretical positions using the riding model with $U_{\text {eq }}(\mathrm{H})=1.2 U_{\mathrm{eq}}(\mathrm{X})$.

\section{Conclusions}

Three new ligands based on 1,4-disubstituted cyclen with two pendant arms containing phosphonic acid, ethyl-phosphonic acid monoester, and H-phosphinic acid functional groups were synthesized. Ligand protonation and complex stability constants with selected metal ions were determined by potentiometric titrations. The phosphonate derivative is the most basic among the ligands, in accordance with the positive inductive effect of the fully deprotonated phosphonate groups. The phosphonate ligand also forms the most stable complexes with all investigated metal ions and is the only one capable of Gd(III) complexation. Both other ligands, $1,4-\mathrm{H}_{2} \mathrm{do} 2 \mathrm{p}^{\mathrm{OEt}}$ and 1,4- $\mathrm{H}_{2} \mathrm{Bn}_{2} \mathrm{do} 2 \mathrm{p}^{\mathrm{H}}$, form significantly weaker complexes and are not able to complex lanthanide(III) ions in respect to competing metal hydroxide precipitation. All ligands are high selective for divalent copper. The Mn(II) complexes of the ligands show low relaxivities. Therefore, there is probably not enough space for a directly coordinated water in their coordination spheres, and the relaxivity is caused only by second-/outer-sphere contributions. A combined ${ }^{1} \mathrm{H}$ NMRD, UV-Vis, and luminescence study on Ln(III) complexes allowed the conclusion that the $\mathrm{Gd}(\mathrm{III})-1,4-\mathrm{H}_{4} \mathrm{do} 2 \mathrm{p}$ complex exists in aqueous solution in an equilibrium of 
mono- and bis-hydrated species, $\left[\mathrm{Gd}(1,4-\mathrm{do} 2 \mathrm{p})\left(\mathrm{H}_{2} \mathrm{O}\right)_{1-2}\right]^{-}$. The complex shows higher relaxivity than the $\left[\mathrm{Gd}(\mathrm{do3a})\left(\mathrm{H}_{2} \mathrm{O}\right)_{2}\right]$ complex with a similar hydration state, probably due to presence of a strong second-sphere hydration induced by the phosphonate groups.

Supplementary Materials: The following data are available online at http:/www.mdpi.com/1420-3049/24/18/ 3324/s1: Synthesis of 1,4-dibenzyl-1,4,7,10-tetraazacyclododecane (1); Figure S1. Hydrogen bond network found in the crystal structure of $1,4-\mathrm{H}_{4} \mathrm{do} 2 \mathrm{p} \cdot 4 \mathrm{H}_{2} \mathrm{O}$; Table S1. Geometric parameters of hydrogen bond network found in the crystal structure of $1,4-\mathrm{H}_{4} \mathrm{do} 2 \mathrm{p} \cdot 4 \mathrm{H}_{2} \mathrm{O}$. Table S2. Experimental values of overall protonation/stability constants $\left(\log \beta_{h l m}\right)$ of the ligands $1,4-\mathrm{H}_{4} \mathrm{do} 2 \mathrm{p}, 1,4-\mathrm{H}_{2} \mathrm{do} 2 \mathrm{p}^{\mathrm{OEt}}$ and $1,4-\mathrm{H}_{2} \mathrm{Bn}_{2} \mathrm{do} 2 \mathrm{p}^{\mathrm{H}}$ and their complexes with metal ions; Figure S2. Distribution diagrams of differently protonated species of the studied ligands; Figure S3. Distribution diagrams for the $\mathrm{Cu}(\mathrm{II})$-studied ligand systems; Figure S4. Distribution diagrams of species present in $\mathrm{Zn}(\mathrm{II})$-studied ligand mixtures; Figure S5. ${ }^{1} \mathrm{H}$ NMRD profiles of Mn(II)-1,4- $\mathrm{H}_{2} \mathrm{do} 2 \mathrm{p}^{\mathrm{OEt}}$ and $\mathrm{Mn}(\mathrm{II})-1,4-\mathrm{H}_{2} \mathrm{Bn}_{2} \mathrm{do} 2 \mathrm{p}^{\mathrm{H}}$ complexes; Figure S6. Temperature dependence of ${ }^{5} \mathrm{D}_{0} \leftarrow{ }^{7} \mathrm{~F}_{0}$ transition in absorption spectra of $\mathrm{Eu}(\mathrm{III})-1,4-\mathrm{H}_{4} \mathrm{do} 2 \mathrm{p}$ complex.

Author Contributions: Conceptualization, P.H.; methodology, J.B., P.H. and J.K.; formal analysis, J.B. and J.K.; investigation, J.B. and J.K.; writing—original draft preparation, J.B.; writing—review and editing, P.H. and J.K.; supervision, P.H. and J.K.; project administration, P.H. and J.K.; funding acquisition, P.H.

Funding: This research was funded by Ministry of Education of the Czech Republic, grant number LTC 17607. The work was performed in the framework of the EU COST CA15209 Action.

Acknowledgments: J.B. thanks E. Tóth (Centre de Biophysique Moléculaire, CNRS, Orléans, France) for the possibility to measure ${ }^{1} \mathrm{H}$ NMRD profiles. The authors thank I. Císařová for X-ray data acquisition and J. Havlíčková for the titration experiments.

Conflicts of Interest: The authors declare no conflict of interest.

\section{References}

1. Hermann, P.; Kotek, J.; Kubíček, J.; Lukeš, I. Gadolinium(III) Complexes as MRI Contrast Agents: Ligand Design and Properties of the Complexes. Dalton Trans. 2008, 3027-3047. [CrossRef] [PubMed]

2. Terreno, E.; Castelli, D.D.; Viale, A.; Aime, S. Challenges for Molecular Magnetic Resonance Imaging. Chem. Rev. 2010, 110, 3019-3042. [CrossRef] [PubMed]

3. Dorazio, S.J.; Olatunde, A.O.; Tsitovich, P.B.; Morrow, J.R. Comparison of divalent transition metal ion paraCEST MRI contrast agents. J. Biol. Inorg. Chem. 2014, 19, 191-205. [CrossRef] [PubMed]

4. Angelovski, G. Heading toward Macromolecular and Nanosized Bioresponsive MRI Probes for Successful Functional Imaging. Acc. Chem. Res. 2017, 50, 2215-2224. [CrossRef] [PubMed]

5. Contrast Agents for MRI. Experimental Methods; Pierre, V.C., Allen, M.J., Eds.; Royal Society of Chemistry: Croydon, UK, 2018.

6. Clough, T.J.; Jiang, L.; Wong, K.-L.; Long, N.J. Ligand Design Strategies to Increase Stability of Gadolinium-Based Magnetic Resonance Imaging Contrast Agents. Nat. Commun. 2019, 10, 1420. [CrossRef] [PubMed]

7. Kueny-Stotz, M.; Garofalo, A.; Felder-Flesch, D. Manganese-Enhanced MRI Contrast Agents: From Small Chelates to Nanosized Hybrids. Eur. J. Inorg. Chem. 2012, 1987-2005. [CrossRef]

8. Drahoš, B.; Lukeš, I.; Tóth, É. Manganese(II) Complexes as Potential Contrast Agents for MRI. Eur. J. Inorg. Chem. 2012, 1975-1986. [CrossRef]

9. Caravan, P.; Ellison, J.J.; McMurry, T.J.; Lauffer, R.B. Gadolinium(III) Chelates as MRI Contrast Agents: Structure, Dynamics, and Applications. Chem. Rev. 1999, 99, 2293-2352. [CrossRef] [PubMed]

10. Wahsner, J.; Gale, E.M.; Rodríguez-Rodríguez, A.; Caravan, P. Chemistry of MRI Contrast Agents: Current Challenges and New Frontiers. Chem. Rev. 2019, 119, 957-1057. [CrossRef] [PubMed]

11. Merbach, A.E.; Helm, L.; Tóth, É. (Eds.) The Chemistry of Contrast Agents in Medical Magnetic Resonance Imaging, 2nd ed.; John Wiley \& Sons: Chichester, UK, 2013.

12. Thomsen, H.S.; Morcos, S.K.; Almén, T.; Bellin, M.-F.; Bertolotto, M.; Bongartz, G.; Clement, O.; Leander, P.; Heinz-Peer, G.; Reimer, P.; et al. Nephrogenic Systemic Fibrosis and Gadolinium-Based Contrast Media: Updated ESUR Contrast Medium Safety Committee Guidelines. Eur. Radiol. 2013, 23, 307-318. [CrossRef] 
13. Runge, V.M.; Dechelation (Transmetalation). Consequences and Safety Concerns With the Linear Gadolinium-Based Contrast Agents, In View of Recent Health Care Rulings by the EMA (Europe), FDA (United States), and PMDA (Japan). Invest. Radiol. 2018, 53, 571-578. [PubMed]

14. Le Fur, M.; Caravan, P. The biological fate of gadolinium-based MRI contrast agents: A call to action for bioinorganic chemists. Metallomics 2019, 11, 240-254. [CrossRef] [PubMed]

15. Christianson, D.W. Structural Chemistry and Biology of Manganese Metalloenzymes. Prog. Biophys. Mol. Biol. 1997, 67, 217-252. [CrossRef]

16. Koretsky, A.P.; Silva, A.C. Manganese Enhanced Magnetic Resonance Imaging (MEMRI). NMR Biomed. 2004, 17, 527-631. [CrossRef] [PubMed]

17. Wolf, G.L.; Burnett, K.R.; Goldstein, E.J.; Joseph, P.M. Magnetic Resonance Annual 1985; Kressel, H., Ed.; Raven: New York, NY, USA, 1985; pp. 231-266.

18. Rocklage, S.M.; Cacheris, W.P.; Quay, S.C.; Hahn, F.E.; Raymond, K.N. Manganese(II) $\mathrm{N}, \mathrm{N}^{\prime}$-dipyridoxylethylenediamine-N,N'-diacetate 5,5'-bis(phosphate). Synthesis and Characterization of a Paramagnetic Chelate for Magnetic Resonance Imaging Enhancement. Inorg. Chem. 1989, 28, 477-485. [CrossRef]

19. Kettritz, U.; Schlund, J.F.; Wilbur, K.; Eisenberg, L.B.; Semelka, R.C. Comparison of Gadolinium Chelates with Manganese-DPDP for Liver Lesion Detection and Characterization: Preliminary Results. Magn. Reson. Imaging 1996, 14, 1185-1190. [CrossRef]

20. Murakami, T.; Baron, R.L.; Peterson, M.S.; Oliver, J.H., 3rd; Davis, P.L.; Confer, S.R.; Federle, M.P. Hepatocellular Carcinoma: MR Imaging with Mangafodipir Trisodium (Mn-DPDP). Radiology 1996, 200, 69-77. [CrossRef]

21. Gallez, B.; Baudelet, C.; Geurts, M. Regional Distribution of Manganese Found in the Brain after Injection of a Single Dose of Manganese-Based Contrast Agents. Magn. Reson. Imaging 1998, 16, 1211-1215. [CrossRef]

22. Cersosimo, M.G.; Koller, W.C. The Diagnosis of Manganese-Induced Parkinsonism. Neurotoxicology 2006, 27, 340-346. [CrossRef]

23. Price, E.W.; Orvig, C. Matching Chelators to Radiometals for Radiopharmaceuticals. Chem. Soc. Rev. 2014, 43, 260-290. [CrossRef]

24. Boros, E.; Packard, A.B. Radioactive Transition Metals for Imaging and Therapy. Chem. Rev. 2019, 119, 870-901.

25. Kostelnik, T.I.; Orvig, C. Radioactive Main Group and Rare Earth Metals for Imaging and Therapy. Chem. Rev. 2019, 119, 902-956. [CrossRef] [PubMed]

26. McInnes, L.E.; Rudd, S.E.; Donnelly, P.S. Copper, Gallium and Zirconium Positron Emission Tomography Imaging Agents: The Importance of Metal Ion Speciation. Coord. Chem. Rev. 2017, 352, 499-516. [CrossRef]

27. Amoroso, A.J.; Fallis, I.A.; Pope, S.J.A. Chelating Agents for Radiolanthanides: Applications to Imaging and Therapy. Coord. Chem. Rev. 2017, 340, 198-219. [CrossRef]

28. Huskens, J.; Torres, D.A.; Kovacs, Z.; André, J.P.; Geraldes, C.F.G.C.; Sherry, A.D. Alkaline Earth Metal and Lanthanide(III) Complexes of Ligands Based upon 1,4,7,10-Tetraazacyclododecane-1,7-bis(acetic acid). Inorg. Chem. 1997, 36, 1495-1503. [CrossRef] [PubMed]

29. Bianchi, A.; Calabi, L.; Giorgi, C.; Losi, P.; Mariani, P.; Palano, D.; Paoli, P.; Rossi, P.; Valtancoli, B. Thermodynamic and Structural Aspects of Manganese(II) Complexes with Polyaminopolycarboxylic Ligands Based upon 1,4,7,10-Tetraazacyclododecane (Cyclen). Crystal Structure of Dimeric $[\mathrm{MnL}]_{2} \cdot 2 \mathrm{CH}_{3} \mathrm{OH}$ Containing the New Ligand 1,4,7,10-Tetraazacyclododecane-1,4-diacetate. J. Chem. Soc. Dalton Trans. 2001, 917-922.

30. Rolla, G.A.; Platas-Iglesias, C.; Botta, M.; Tei, L.; Helm, L. ${ }^{1} \mathrm{H}$ and ${ }^{17} \mathrm{O}$ NMR Relaxometric and Computational Study on Macrocyclic Mn(II) Complexes. Inorg. Chem. 2013, 52, 3268-3279.

31. Rolla, G.; De Biasio, V.; Giovenzana, G.B.; Botta, M.; Tei, L. Supramolecular Assemblies Based on Amphiphilic $\mathrm{Mn}^{2+}$-Complexes as High Relaxivity MRI Probes. Dalton Trans. 2018, 47, 10660-10670. [CrossRef] [PubMed]

32. Garda, Z.; Forgács, A.; Do, Q.N.; Kálmán, F.K.; Timári, S.; Baranyai, Z.; Tei, L.; Tóth, I.; Kovács, Z.; Tircsó, G. Physico-Chemical Properties of $\mathrm{Mn}^{\mathrm{II}}$ Complexes Formed with Cis- and Trans-DO2A: Thermodynamic, Electrochemical and Kinetic Studies. J. Inorg. Biochem. 2016, 163, 206-213. [CrossRef] [PubMed]

33. Forgács, A.; Tei, L.; Baranyai, Z.; Tóth, I.; Zékány, L.; Botta, M. A Bisamide Derivative of [Mn(1,4-DO2A)]—Solution Thermodynamic, Kinetic, and NMR Relaxometric Studies. Eur. J. Inorg. Chem. 2016, 1165-1174. [CrossRef] 
34. Burai, L.; Ren, J.; Kovacs, Z.; Brücher, E.; Sherry, A.D. Synthesis, Potentiometry, and NMR Studies of Two New 1,7-Disubstituted Tetraazacyclododecanes and Their Complexes Formed with Lanthanide, Alkaline Earth Metal, $\mathrm{Mn}^{2+}$, and $\mathrm{Zn}^{2+}$ Ions. Inorg. Chem. 1998, 37, 69-75. [CrossRef] [PubMed]

35. Bellouard, F.; Chuburu, F.; Kervarec, N.; Toupet, L.; Triki, S.; Le Mest, Y.; Handel, H. Cis-Diprotected Cyclams and Cyclens: A New Route to Symmetrically or Asymmetrically 1,4-Disubstituted Tetraazamacrocycles and to Asymmetrically Tetrasubstituted Derivatives. J. Chem. Soc. Perkin Trans. 1 1999, 3499-3505. [CrossRef]

36. Sun, X.; Wuest, M.; Kovacs, Z.; Sherry, D.A.; Motekaitis, R.; Wang, Z.; Martell, A.E.; Welch, M.J.; Anderson, C.J. In Vivo Behavior of Copper-64-Labeled Methanephosphonate Tetraaza Macrocyclic Ligands. J. Biol. Inorg. Chem. 2003, 8, 217-225. [CrossRef] [PubMed]

37. Lebdušková, P.; Hermann, P.; Helm, L.; Tóth, É.; Kotek, J.; Binnemans, K.; Rudovský, J.; Lukeš, I.; Merbach, A.E. Gadolinium(III) Complexes of Mono- and Diethyl Esters of Monophosphonic Acid Analogue of DOTA as Potential MRI Contrast Agents: Solution Structures and Relaxometric Studies. Dalton Trans. 2007, 493-501. [CrossRef] [PubMed]

38. Försterová, M.; Jandurová, Z.; Marques, F.; Gano, L.; Lubal, P.; Vaněk, J.; Hermann, P.; Santos, I. Chemical and Biological Evaluation of ${ }^{153} \mathrm{Sm}$ and ${ }^{166} \mathrm{Ho}$ Complexes of 1,4,7,10-Tetraazacyclododecane-1,4,7,10-tetrakis(methylphosphonic acid monoethylester) $\left(\mathrm{H}_{4}\right.$ dotp $\left.^{\mathrm{OEt}}\right)$. J. Inorg. Biochem. 2008, 102, 1531-1540. [CrossRef] [PubMed]

39. Kotek, J.; Vojtíšek, P.; Císařová, I.; Hermann, P.; Jurečka, P.; Rohovec, J.; Lukeš, I. Bis(methylphosphonic Acid) Derivatives of 1,4,8,11-Tetraazacyclotetradecane (Cyclam). Synthesis, Crystal and Molecular Structures, and Solution Properties. Collect. Czech. Chem. Commun. 2000, 65, 1289-1316. [CrossRef]

40. Meyer, M.; Dahaoui-Gindrey, V.; Lecomte, C.; Guilard, R. Conformations and Coordination Schemes of Carboxylate and Carbamoyl Derivatives of the Tetraazamacrocycles Cyclen and Cyclam, and the Relation to their Protonation States. Coord. Chem. Rev. 1998, 178-180, 1313-1405. [CrossRef]

41. Pniok, M.; Kubíček, V.; Havlíčková, J.; Kotek, J.; Sabatie-Gogová, A.; Plutnar, J.; Huclier-Markai, S.; Hermann, P. Thermodynamic and Kinetic Study of Scandium(III) Complexes of DTPA and DOTA: A Step Toward Scandium Radiopharmaceuticals. Chem. Eur. J. 2014, 20, 7944-7955. [CrossRef]

42. Lukeš, I.; Kotek, J.; Vojtíšek, P.; Hermann, P. Complexes of Tetraazacycles Bearing Methylphosphinic /phosphonic Acid Pendant Arms with Copper(II), Zinc(II) and Lanthanides(III). A Comparison with their Acetic Acid Analogues. Coord. Chem. Rev. 2001, 216-217, 287-312. [CrossRef]

43. Lima, L.M.P.; Delgado, R.; Hermann, P.; Ševčík, R.; Lubal, P.; Carvalho, H.F.; Martins, A.F.; Tóth, É.; Geraldes, C.F.G.C. Tris(phosphonomethyl)cyclen Derivatives: Thermodynamic Stability, Kinetics, Solution Structure, and Relaxivity of $\mathrm{Ln}^{3+}$ Complexes. Eur. J. Inorg. Chem. 2012, 2548-2559. [CrossRef]

44. Lima, L.M.P.; Esteves, C.V.; Delgado, R.; Hermann, P.; Kotek, J.; Ševčíková, R.; Lubal, P. Tris(phosphonomethyl) Cyclen Derivatives: Synthesis, Acid-Base Properties and Complexation Studies with $\mathrm{Cu}^{2+}$ and $\mathrm{Zn}^{2+}$ Ions. Eur. J. Inorg. Chem. 2012, 15, 2533-2547. [CrossRef]

45. Marques, F.; Gano, L.; Paula Campello, M.; Lacerda, S.; Santos, I.; Lima, L.M.P.; Costa, J.; Antunes, P.; Delgado, R. 13- and 14-Membered Macrocyclic Ligands Containing Methylcarboxylate or Methylphosphonate Pendant Arms: Chemical and Biological Evaluation of their ${ }^{153} \mathrm{Sm}$ and ${ }^{166} \mathrm{Ho}$ Complexes as Potential Agents for Therapy or Bone Pain Palliation. J. Inorg. Biochem. 2006, 100, 270-280. [CrossRef] [PubMed]

46. Kumar, K.; Chang, C.A.; Francesconi, L.C.; Dischino, D.D.; Malley, M.F.; Gougoutas, J.Z.; Tweedle, M.F. Synthesis, Stability, and Structure of Gadolinium(III) and Yttrium(III) Macrocyclic Poly(amino carboxylates). Inorg. Chem. 1994, 33, 3567-3575. [CrossRef]

47. Takács, A.; Napolitano, R.; Purgel, M.; Bényei, A.C.; Zékány, L.; Brücher, E.; Tóth, I.; Baranyai, Z.; Aime, S. Solution Structures, Stabilities, Kinetics, and Dynamics of DO3A and DO3A-Sulphonamide Complexes. Inorg. Chem. 2014, 53, 2858-2872. [CrossRef] [PubMed]

48. Bianchi, A.; Calabi, L.; Ferrini, L.; Losi, P.; Uggeri, F.; Valtancoli, B. Thermodynamics of Gd(III) Complexation by Macrocyclic and Acyclic Polyamino Carboxylates. Inorg. Chim. Acta 1996, 249, 13-15. [CrossRef]

49. Bianchi, A.; Calabi, L.; Giorgi, C.; Losi, P.; Mariani, P.; Paoli, P.; Rossi, P.; Valtancoli, B.; Virtuani, M. Thermodynamic and Structural Properties of $\mathrm{Gd}^{3+}$ Complexes with Functionalized Macrocyclic Ligands Based upon 1,4,7,10-Tetraazacyclododecane. J. Chem. Soc. Dalton Trans. 2000, 697-705. [CrossRef]

50. Kumar, K.; Chang, C.A.; Tweedle, M.F. Equilibrium and Kinetic Studies of Lanthanide Complexes of Macrocyclic Polyamino Carboxylates. Inorg. Chem. 1993, 32, 587-593. [CrossRef] 
51. Polášek, M.; Caravan, P. Is Macrocycle a Synonym for Kinetic Inertness in Gd(III) Complexes? Effect of Coordinating and Noncoordinating Substituents on Inertness and Relaxivity of Gd(III) Chelates with DO3A-like Ligands. Inorg. Chem. 2013, 52, 4084-4096. [CrossRef]

52. Caravan, P.; Esteban-Gómez, D.; Rodríguez-Rodríguez, A.; Platas-Iglesias, C. Water exchange in lanthanide complexes for MRI applications. Lessons learned over the last 25 years. Dalton Trans. 2019, 48, 11161-11180. [CrossRef]

53. Drahoš, B.; Kubíček, V.; Bonnet, C.S.; Hermann, P.; Lukeš, I.; Tóth, É. Dissociation kinetics of Mn2+ complexes of NOTA and DOTA. Dalton Trans. 2011, 40, 1945-1951. [CrossRef]

54. Wang, S.; Westmoreland, T.D. Correlation of Relaxivity with Coordination Number in Six-, Seven-, and Eight-Coordinate Mn(II) Complexes of Pendant-Arm Cyclen Derivatives. Inorg. Chem. 2009, 48, 719-727. [CrossRef] [PubMed]

55. Kálmán, F.K.; Baranyai, Z.; Tóth, I.; Bányai, I.; Király, R.; Brücher, E.; Aime, S.; Sun, X.; Sherry, A.D.; Kovács, Z. Synthesis, Potentiometric, Kinetic, and NMR Studies of 1,4,7,10-Tetraazacyclododecane-1,7-bis(acetic acid)-4,10-bis(methylenephosphonic acid) (DO2A2P) and its Complexes with $\mathrm{Ca}(\mathrm{II}), \mathrm{Cu}(\mathrm{II}), \mathrm{Zn}(\mathrm{II})$ and Lanthanide(III) Ions. Inorg. Chem. 2008, 47, 3851-3862. [CrossRef] [PubMed]

56. Tóth, É;; Dhubhghaill, O.M.N.; Besson, G.; Helm, L.; Merbach, A.E. Coordination equilibrium-A clue for fast water exchange on potential magnetic resonance imaging contrast agents? Magn. Reson. Chem. 1999, 37, 701-708. [CrossRef]

57. Kimpe, K.; D’Olieslager, W.; Görller-Walrand, C.; Figueirinha, A.; Kovács, Z.; Geraldes, C.F.G.C. Interaction of $\left[\mathrm{Ln}(\mathrm{DO} 2 \mathrm{~A})\left(\mathrm{H}_{2} \mathrm{O}\right)_{2-3}\right]^{+}$and $\left[\mathrm{Ln}(\mathrm{DO} 2 \mathrm{P})\left(\mathrm{H}_{2} \mathrm{O}\right)_{2-3}\right]^{-}$with Phosphate, Acetate and Fluoride Anions in Aqueous Solution. J. Alloys Compd. 2001, 323-324, 828-832. [CrossRef]

58. Horrocks, W.D.; Sudnick, D.R. Lanthanide Ion Probes of Structure in Biology. Laser-Induced Luminescence Decay Constants Provide a Direct Measure of the Number of Metal-Coordinated Water Molecules. J. Am. Chem. Soc. 1979, 101, 334-340. [CrossRef]

59. Clarkson, I.; Dickins, R.; de Sousa, A. Non-Radiative Deactivation of the Excited States of Europium, Terbium and Ytterbium Complexes by Proximate Energy-Matched $\mathrm{OH}, \mathrm{NH}$ and $\mathrm{CH}$ Oscillators: An Improved Luminescence Method for Establishing Solution Hydration States. J. Chem. Soc. Perkin Trans. 2 1999, $493-504$.

60. Supkowski, R.M.; Horrocks, W.D., Jr. On the Determination of the Number of Water Molecules, q, Coordinated to Europium(III) Ions in Solution from Luminescence Decay Lifetimes. Inorg. Chim. Acta 2002, 340, 44-48. [CrossRef]

61. Graeppi, N.; Hugh Powell, D.; Laurenczy, G.; Zékány, L.; Merbach, A. Coordination equilibria and water exchange kinetics of lanthanide(III) propylenediaminetetraacetates and other magnetic resonance imaging related complexes. Inorg. Chim. Acta 1995, 235, 311-326. [CrossRef]

62. Perrin, D.D. Purification of Laboratory Chemicals; Pergamon Press: Oxford, UK, 1988.

63. Kývala, M. OPIUM - Program for Solution Equilibria Analysis; Charles University: Prague, Czech Republic, 1995.

64. Kývala, M.; Lukeš, I. Chemometrics '95 (International conference); University of Pardubice: Pardubice, Czech Republic, 1995; p. 63.

65. Martell, A.E.; Smith, R.M. Critical Stability Constants; Plenum Press: New York, NY, USA, 1974-1989; pp. 1-6.

66. NIST Standard Reference Database 46 (Critically Selected Stability Constants of Metal Complexes), Version 7.0; National Institute for Standards and Technology: Gaithersburg, MD, USA, 2003.

67. Baes, C.F., Jr.; Mesmer, R.E. The Hydrolysis of Cations; Wiley: New York, NY, USA, 1976.

68. Försterová, M.; Svobodová, I.; Lubal, P.; Táborský, P.; Kotek, J.; Hermann, P.; Lukeš, I. Thermodynamic Study of Lanthanide(III) Complexes with Bifunctional Monophosphinic Acid Analogues of $\mathrm{H}_{4}$ dota and Comparative Kinetic Study of Yttrium(III) Complexes. Dalton Trans. 2007, 535-549. [CrossRef]

69. Kubíček, V.; Kotek, J.; Hermann, P.; Lukeš, I. Aminoalkyl-bis(phosphonates): Their Complexation Properties in Solution and in the Solid State. Eur. J. Inorg. Chem. 2007, 333-344. [CrossRef]

70. Otwinowski, Z.; Minor, W. HKL Denzo and Scalepack Program Package; Nonius BV: Delft, The Netherlands, 1997.

71. Otwinowski, Z.; Minor, W. Processing of X-ray diffraction data collected in oscillation mode. Methods Enzymol. 1997, 276, 307-326.

72. Sheldrick, G.M. SHELXS97. Program for Crystal Structure Solution from Diffraction Data; University of Göttingen: Göttingen, Germany, 1997. 
73. Sheldrick, G.M. A Short History of SHELX. Acta Crystallogr. A 2008, 64, 112-122. [CrossRef] [PubMed]

74. Sheldrick, G.M. SHELXL-2014/7. Program for Crystal Structure Refinement from Diffraction Data; University of Göttingen: Göttingen, Germany, 2014.

Sample Availability: Samples of the compounds $\mathrm{H}_{4} \mathrm{~L} 1, \mathrm{H}_{2} \mathrm{~L} 2$ and $\mathrm{H}_{2} \mathrm{~L} 3$ are available from the authors.

(C) 2019 by the authors. Licensee MDPI, Basel, Switzerland. This article is an open access article distributed under the terms and conditions of the Creative Commons Attribution (CC BY) license (http://creativecommons.org/licenses/by/4.0/). 